\title{
Abstracts of Shellfish Technical Papers, Presented at the Joint Meeting of the Northeast Aquaculture Conference and Exposition and the 35th Milford Aquaculture Seminar, Portland, Maine, January 14-16, 2015
}

National Shellfisheries Association

Follow this and additional works at: https://scholarworks.wm.edu/vimsarticles

Part of the Aquaculture and Fisheries Commons

\section{Recommended Citation}

National Shellfisheries Association, "Abstracts of Shellfish Technical Papers, Presented at the Joint Meeting of the Northeast Aquaculture Conference and Exposition and the 35th Milford Aquaculture Seminar, Portland, Maine, January 14-16, 2015" (2015). VIMS Articles. 522.

https://scholarworks.wm.edu/vimsarticles/522

This Article is brought to you for free and open access by W\&M ScholarWorks. It has been accepted for inclusion in VIMS Articles by an authorized administrator of W\&M ScholarWorks. For more information, please contact scholarworks@wm.edu. 


\title{
ABSTRACTS OF SHELLFISH TECHNICAL PAPERS
}

Presented at the joint meeting of the

NORTHEAST AQUACULTURE CONFERENCE AND EXPOSITION

and the

\section{$35^{\text {th }}$ MILFORD AQUACULTURE SEMINAR}

\author{
Portland, Maine
}

January 14-16, 2015 


\section{CONTENTS}

Abigail Archer, Josh Reitsma, Diane Murphy

COMPARISON OF BOTTOM AND FLOATING GEAR FOR GROWING EASTERN OYSTERS

(CRASSOSTREA VIRGINICA) IN SOUTHEASTERN MASSACHUSETTS . . . . . . . . . . . . .

Brian Beal, Cody Jourdet, George Protopopescu, Kyle Pepperman, Christopher Davis, Sandra Shumway, Kevin Athearn ARCTIC SURFCLAM, MACTROMERIS POLYNYMA, CULTURE AT THE DOWNEAST INSTITUTE: EXPLORING METHODS TO DIVERSIFY DOMESTIC SEAFOOD BY CREATING A NEW,

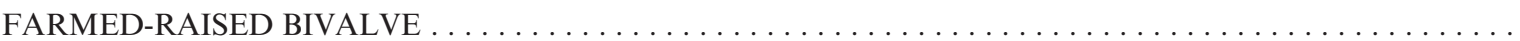

Brian Beal, Chad Coffin, Clint Goodenow, Sara Randall GREEN CRAB, CARCINUS MAENAS, WARS IN SOUTHERN MAINE: MANAGING PUBLIC SHELLFISH STOCKS DURING TIMES OF EXPLODING PREDATOR ABUNDANCE . . . . . . . . . .

Brian Beal, Kyle Pepperman, George Protopopescu, Cody Jourdet, Scott Lindell ANNUAL CONSISTENCY IN BLUE MUSSEL, MYTILUS EDULIS, SEED PRODUCTION USING HATCHERY

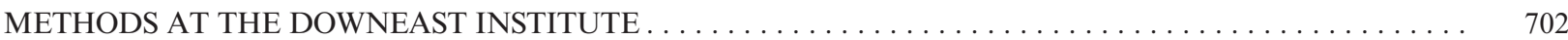

Daniel Belknap, Kristin Wilson INVASIVE EUROPEAN GREEN CRABS: SUDDEN INCREASE IN EROSION POTENTIAL ON SALT MARSHES IN SOUTHERN AND CENTRAL COASTAL MAINE $\ldots \ldots \ldots \ldots \ldots \ldots \ldots \ldots \ldots \ldots \ldots$

David Beutel, Azure Cygler, Monique LaFrance, Dale Leavitt, Jennifer McCann, Jeff Mercer AQUACULTURE AND THE RHODE ISLAND SHELLFISH MANAGEMENT PLAN $\ldots \ldots \ldots \ldots \ldots \ldots$

April Blakeslee, Joe Roman NORTHWEST ATLANTIC POPULATION STRUCTURE AND GENE FLOW IN THE GREEN CRAB: AN UPDATE ON THE CRAB'S DYNAMIC INVASION FRONT $\ldots \ldots \ldots \ldots \ldots \ldots \ldots \ldots \ldots \ldots \ldots$

Damian Brady, J. M. Testa, Larry P. Sanford, J. C. Cornwell, Roger E. I. Newell, Carter Newell, John Richardson SEDIMENT FLUX MODELING OF BIVALVE AQUACULTURE SPATIAL IMPACTS ON SEDIMENTS (BASIS)

Gary Burr, William Wolters

POTENTIAL USE OF THE INVASIVE EUROPEAN GREEN CRAB (CARCINUS MAENAS) AS AN

INGREDIENT IN ATLANTIC SALMON (SALMO SALAR) DIETS; A PRELIMINARY ANALYSIS ....... .

Carrie Byron, Di Jin, Tracey M. Dalton

AN INTEGRATED ECOLOGICAL-ECONOMIC MODELING FRAMEWORK FOR THE SUSTAINABLE

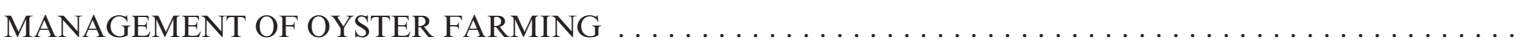

Lisa Calvo, Tal Ben-, David Bushek

EFFECT OF INTERTIDAL EXPOSURE ON VIBRIO PARAHAEMOLYTICUS LEVELS IN DELAWARE BAY

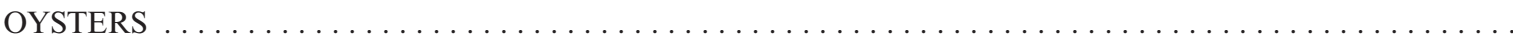

Mary Carmen, Scott Lindell, Emma Green-Beach, Victoria R. Starczak TREATMENTS TO ERADICATE INVASIVE TUNICATE FOULING FROM BLUE MUSSEL SEED AND

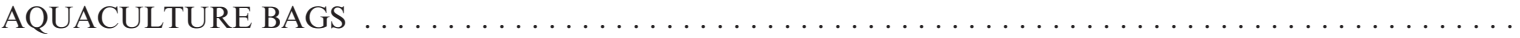

Ryan Carnegie DETECTION OF BIVALVE MOLLUSC PATHOGENS: ARE WE HEADING IN THE RIGHT DIRECTION?

April Croxton, Gary Wikfors INTRACELLULAR PH IN BIVALVE HEMOCYTES AND RESPONSES TO IN VITRO ACID CHALLENGE ...

Soren Dahl, Debra Barnes, Wade Carden, Bassem Allam EPIZOOTIOLOGICAL ANALYSIS OF QPX DISEASE DATA FROM HARD CLAM (AKA QUAHOG) MONITORING IN AN ENZOOTIC ESTUARY $\ldots \ldots \ldots \ldots \ldots \ldots \ldots \ldots \ldots \ldots \ldots \ldots \ldots \ldots \ldots$

Soren Dahl, Bassem Allam WILL CLIMATE CHANGE HELP NEW YORK HARD CLAMS FIGHT DISEASE? . . . . . . . . . . 706

Jonathan P. Davis RECENT DEVELOPMENTS IN PURPLE HINGED ROCK SCALLOP CULTURE ON THE US WEST COAST 706

John der Kinderen PRELIMINARY RESULTS GENERATED BY MTI CIP 163 “UNDER-UTILIZED SHELLFISH PRODUCTS WITH EMPHASIS ON GREEN CRAB" 
Kristin DeRosia-Banick, David Carey and Joseph DeCrescenzo CONNECTICUT'S VIBRIO PARAHAEMOLYTICUS CONTROL PLAN AND MONITORING

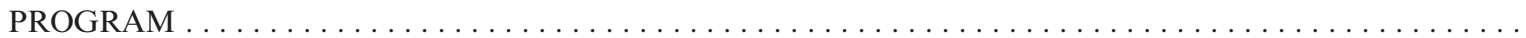

Mark S. Dixon, Genevieve Bernatchez, Eve Galimany, Judy Yaqin Li, Shannon L. Meseck, Julie M. Rose, Gary H. Wikfors DIRECT MEASUREMENTS OF THE NUTRIENT MANAGEMENT POTENTIAL OF RIBBED MUSSELS, GEUKENSIA DEMISSA, AT TWO SITES IN UPPER NARRAGANSETT BAY, RHODE ISLAND . . . . . . . .

Marcel Fréchette, Éric Bujold TWO POTENTIAL PASSIVE ANTI-PREDATOR TECHNIQUES FOR LONGLINE MUSSEL CULTURE . . 708

Marcel Fréchette, José M. Urquiza, Gaétan Daigle, Dominique Rioux-Gagnon CLEARANCE RATE REGULATION IN MUSSELS: ADDING THE EFFECT OF ORGANIC SESTON LEVEL TO A MODEL OF INTERNAL STATE-BASED REGULATION $\ldots \ldots \ldots \ldots \ldots \ldots \ldots \ldots \ldots$

Tessa Getchis, Nancy Balcom, Anoushka Concepcion, Sylvain De Guise, Julie Rose THE CONNECTICUT SHELLFISH INITIATIVE: BUILDING ON THE PAST AND CREATING A VISION FOR THE

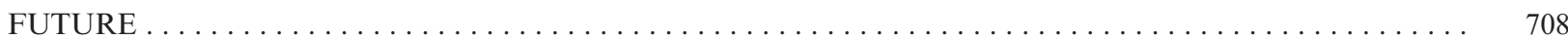

Cem Giray, Diane Murphy, Marcy Nelson SKULKING BEHIND AN MSX SMOKESCREEN: SSO PREVALENCE IN MAINE AND MASSACHUSETTS . . 709

Cem Giray, Victoria Bowie, Christopher Davis, William Mook VIBRIO PARAHAEMOLYTICUS PREVALENCE IN MAINE OYSTERS . . . . . . . . . . . . . . 709

Ronald Goldberg, Julie M. Rose, Renee Mercaldo-Allen, Shannon Meseck SUMMARIZING MILFORD LABORATORY'S RESEARCH ON THE ECOLOGICAL EFFECTS OF HYDRAULIC DREDGING, AS USED IN CLAM CULTIVATION IN LONG ISLAND SOUND . . . . . . . . . . . . 709

Marta Gomez-Chiarri, Dina Proestou, Ryan Corbet, Kehan Bao, Jessica Piesz, Anu Frank-Lawale, Ximing Guo, Paul Rawson, Standish K. Allen Jr. PERFORMANCE OF SELECTIVELY-BRED LINES OF EASTERN OYSTERS, CRASSOSTREA VIRGINICA, AT DIFFERENT LOCATIONS ALONG THE EAST COAST OF THE UNITED STATES $\ldots \ldots \ldots \ldots$

Emma Green-Beach, Richard Karney, Amandine Surier, Chris Edwards DEMONSTRATION OF LIVING SHORELINE TECHNOLOGY ON MARTHA'S VINEYARD, MA . . . . . 710

Zach Hope DERIVED MACROALGAE FEED AND ITS POTENTIAL USE IN SHELLFISH AQUACULTURE . . . . 710

Whitney Jaillet, Kathryn Markey, Roxanna Smolowitz THE APPLICATION OF A QUANTITATIVE PCR WITH A PLASMID STANDARD CURVE TO EVALUATE PERKINSUS MARINUS LEVELS IN THE EASTERN OYSTER, CRASSOSTREA VIRGINICA . . . . . . . . . .

Stephen H. Jones, Erin Urquhart, Meghan Hartwick, Michael Taylor, Vaughn S. Cooper, Cheryl A. Whistler LONG-TERM TRENDS OF PATHOGENIC VIBRIO SPP. POPULATIONS IN NEW HAMPSHIRE OYSTERS 711

Kohl Kanwit, Alison Sirois, Meggan Dwyer SHELLFISH SANITATION MANAGEMENT FRAMEWORK FOR AQUACULTURE SCALLOPS ......

Diane Kapareiko, Harold Schreier, Eric Schott, Dorothy Jeffress, Gary Wikfors HUMAN HEALTH SAFETY CONSIDERATIONS FOR USING VIBRIO SP. PROBIOTIC STRAIN OY15 AS A FEED SUPPLEMENT TO IMPROVE SURVIVAL OF LARVAE OF THE EASTERN OYSTER (CRASSOSTREA VIRGINICA): GENOME SEQUENCING AND MAMMALIAN CYTOTOXICITY ASSAY $\ldots \ldots \ldots \ldots \ldots 12$

Richard Karney, Emma Green-Beach, Paul Carey GETTING THE N OUT - A SEARCH FOR BIOREMEDIATION ALTERNATIVES TO SEWAGE TREATMENT 712

Amanda Keegan, Mark Fregeau PREDATION ON JUVENILE SOFT SHELL CLAMS: THE SCOURGE OF THE GREEN CRABS . . . . . 712

Judy Yaqin Li, Mark Dixon, Shannon Meseck, Barry Smith, Julie Rose, Gary Wikfors IN VIVO FLUORESCENCE BASED CHLOROPHYLL A MEASUREMENTS - HOW CLOSE ARE WE TO THE TRUTH?

Joseph Looney, Lauren Huey, William Schroer, Tal Ben-Horin, Daphne Munroe, David Bushek VIABILITY OF PERKINSUS MARINUS IN SEAWATER .

Edward (Ted) Maney Jr., Mark Fregeau, Bill Lee ESTABLISHING OFFSHORE MUSSEL FARMS IN FEDERAL WATERS 
Isaiah Mansour, Sheila Stiles, Joseph Choromanski

A PRELIMINARY ASSESSMENT OF THE EFFECT OF INCREASED SEAWATER ACIDITY ON JUVENILE BAY

SCALLOPS (ARGOPECTEN IRRADIANS IRRADIANS) FROM TWO GENETIC LINES $\ldots \ldots \ldots \ldots \ldots$

Kathryn Markey, Roxanna Smolowitz

DEVELOPMENT AND APPLICATION OF A DUPLEX QPCR FOR THE DETECTION OF VIBRIO

PARAHAEMOLYTICUS AND VIBRIO VULNIFICUS IN ENRICHED OYSTER HOMOGENATES FROM RHODE

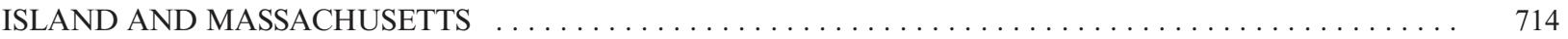

Kelly Markowitz, Maureen Krause, Jason Williams

PREVALENCE, INTENSITY AND MOLECULAR DETECTION OF THE TREMATODE PROCTOECES

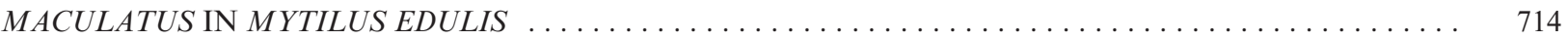

Nicole Messerman

SCREENING BIOFOULING ORGANISMS AROUND OYSTER CAGES FOR POTENTIAL RESERVOIR SPECIES

Bill Mook

OR INTERMEDIATE HOSTS OF THE OYSTER PARASITE MSX IN THE DAMARISCOTTA ESTUARY . . 715

COPING WITH COPIOUS FRESHWATER IN MIDCOAST MAINE $\ldots \ldots \ldots \ldots \ldots$

Dana Morse, Togue Brawn, Marsden Brewer, Terry Gray, Mark Green, Kohl Kanwit, Nate Perry, Kevin Scott, Peter Stocks,

Evan Young PROGRESS IN AQUACULTURE OF SEA SCALLOPS (PLACOPECTEN MAGELLANICUS) IN MAINE . . . 715

Daphne Munroe, Matthew Poach, Ian Abrahamsen, Sarah Borsetti UPWELLING OF ACIDIFIED WATER: NOT JUST AN ISSUE FOR SHELLFISH HATCHERIES ON THE WEST

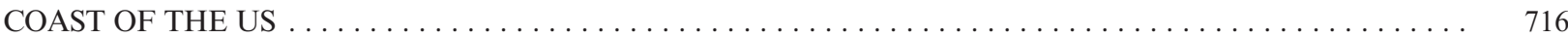

Gulnihal Ozbay, Brian Reckenbeil, Frank Marenghi, Patrick Erbland

ARE THE AQUACULTURE PRACTICES SUSTAINING OUR GOAL TO RESTORE OYSTERS (CRASSOSTREA

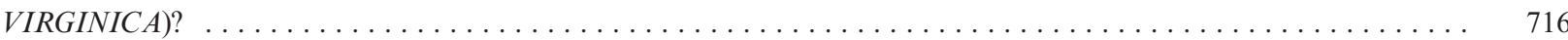

Alisha Patel, Melanie Fuoco, Bradford Bourque, Joseph Szczebak, Andrew Rhyne

PRODUCTION OF THE FIRE SHRIMP (LYSMATA DEBELIUS) USING A CLOSED-LOOP RECIRCULATING

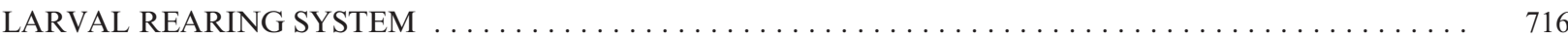

Joe Payne

ACIDIC MUD AND CLAM SHELL PITTING IN CASCO BAY, MAINE $\ldots \ldots \ldots \ldots$

Kyle Pfau, Brian Preziosi, Timothy Bowden

THE EFFECTS OF TEMPERATURE AND PHOTOPERIOD ON BLUE MUSSEL (MYTILUS EDULIS)

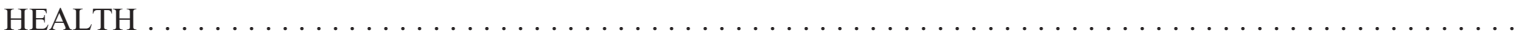

Luke Poirier, Sophie St. Hilaire, Jeff Davidson, Jonathan Hill, Pedro Quijon

THE EUROPEAN GREEN CRAB - FINDING ALTERNATIVE USES FOR AN INVASIVE PREDATOR IN

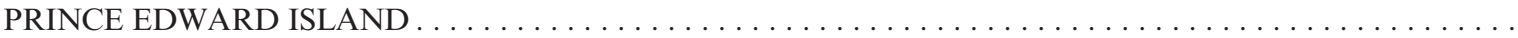

Brian Preziosi, Timothy Bowden

CLASSIFICATION OF ATLANTIC RAZOR CLAM (ENSIS DIRECTUS) HEMOCYTES USING LIGHT AND

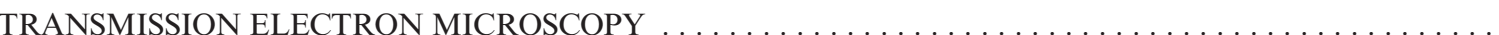

Dina Proestou, Ryan J. Corbett, Marta Gomez-Chiarri, Jessica Moss Small, Standish K. Allen Jr.

ASSESSING THE EXTENT OF PHENOTYPIC VARIATION FOR DERMO RESISTANCE AMONG

SELECTIVELY-BRED FAMILIES OF THE EASTERN OYSTER, CRASSOSTREA VIRGINICA ........

Paul Rawson, Scott Lindell, Ximing Guo, Inke Sunila

DISEASE-RESISTANCE AND IMPROVED PERFORMANCE FOR GENETICALLY IMPROVED AND CROSSBRED EASTERN OYSTERS, CRASSOSTREA VIRGINICA: RESULTS FROM A DECADE OF FIELD TRIALS IN

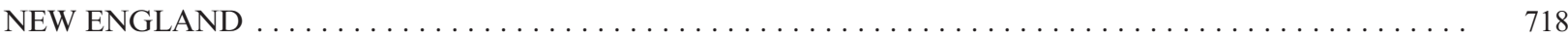

Dylan H. Redman, Dean M. Perry, George Sennefelder, Christina McGraw EXPERIMENTAL SYSTEM DESIGN FOR STUDYING THE EFFECTS OF ELEVATED LEVELS OF CO2 ON

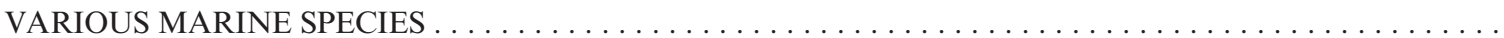

Josh Reitsma, Ed Osmun

FRESH LOCAL SHRIMP IN THE NORTHEAST: CAN RECIRCULATING SYSTEMS MAKE IT

HAPPEN? 
Donald Ronning, Carol R. Foss, Peter Stocks HIGH BRIGHTNESS LEDS DETER EIDER PREDATION AT MUSSEL RAFTS . . .

Julie M. Rose, Suzanne B. Bricker, Tessa Getchis, Cary Chadwick, Cori M. Rose MERGING, MODELING AND MAPPING TO IMPROVE SHELLFISH AQUACULTURE SITE

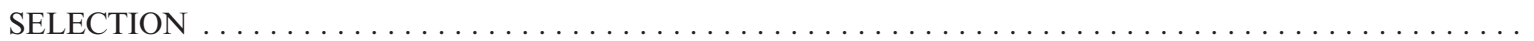

Christopher Schillaci, Eric Hickey, Mike Hickey, Michael Moore, Tom Shields, Kim Foley VIBRIO PARAHAEMOLYTICUS CONTROL FOR OYSTERS IN MASSACHUSETTS $\ldots \ldots \ldots \ldots$

Sandra Shumway SCALLOPS AND ALGAL TOXINS - SAME THREAT DIFFERENT DAY

Saebom Sohn, David Rowley, David Nelson, Roxanna Smolowitz, Marta Gómez-Chiarri THE EFFECTS OF CANDIDATE PROBIOTICS ON SEVERAL SPECIES OF CULTURED LARVAL

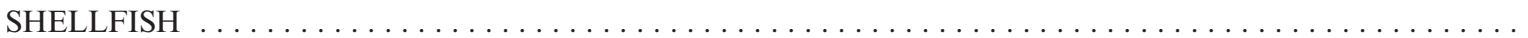

Sophie St-Hilaire, Juergen Krause, Kehar Singh, Luke Poirier, Pedro Quijon, Ian Gardner ECONOMIC ASSESSMENT OF USING A COMMERCIAL FISHERY TO CONTROL THE INVASIVE GREEN

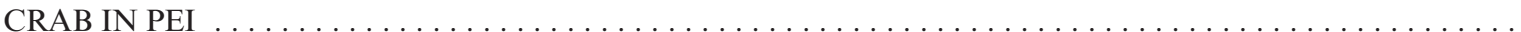

Sheila Stiles, Joseph Choromanski, Dorothy Jeffress GENETIC AND VIABILITY EFFECTS OF PH ON EARLY STAGES OF BAY SCALLOPS FOR

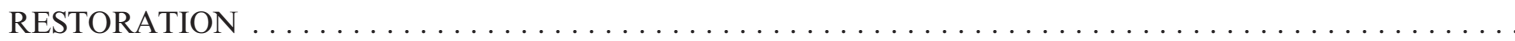

Brett Still, Mark Stolt SUBAQUEOUS SOILS AND COASTAL ACIDIFICATION: A HYDROPEDOLOGY PERSPECTIVE . . . . . 722

Elisabeth Varennes, Magella Guillemette WHY SEADUCKS FORAGE IN MUSSEL FARMS? PREFERENCES AND EFFICIENCIES WHEN FORAGING ON CULTIVATED OR INTERTIDAL MUSSELS $\ldots \ldots \ldots \ldots \ldots \ldots \ldots \ldots \ldots$

Elisabeth Varennes, Sveinn Are Hanssen, John Bonardelli, Magella Guillemette SEA DUCK PREDATION IN MUSSEL FARMS: THE BEST NETS FOR EXCLUDING COMMON EIDERS SAFELY AND EFFICIENTLY

Sarah Vedder, Erin DeBiaso, Britney Wrightington, John Roy AN INITIAL LOOK AT BATCH CULTURE OF JUVENILE AMERICAN LOBSTERS AND HOMARUS AMERICANUS, AT THE SOUND SCHOOL AQUACULTURE CENTER $\ldots \ldots \ldots \ldots \ldots \ldots \ldots$

David Veilleux, Lisa Milke COMPARISON OF GROWTH AND SURVIVAL OF THE LARVAL EASTERN OYSTER (CRASSOSTREA VIRGINICA) FED BY DIFFERENT METHODS

Pandora Wadsworth, Scott Rutherford, Dale Leavitt APPLYING LAGRANGIAN DRIFTERS AND HYDRODYNAMIC MODELING TO SITE SELECTION IN

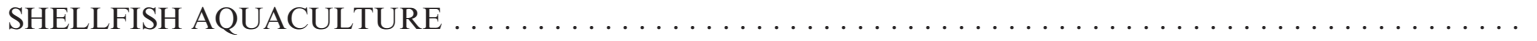

Alex Walsh, Sandra Shumway, Stephan Bullard, Steven Fisher DEVELOPMENT OF NOVEL ANTIFOULING COATINGS FOR THE AQUACULTURE INDUSTRY . . . 724

Daniel Ward, Alex Walsh NOVEL ANTI-PREDATOR COATINGS FOR SHELLFISH AQUACULTURE $\ldots \ldots \ldots \ldots 24$

Don Webster, Don Meritt, Alan Roache, Steven Weschler, Stephan Abel, Jillian Parisi REMOTE SETTING TRAINING PROGRAM: SUPPORTING SEED PRODUCTION FOR MARYLAND OYSTER

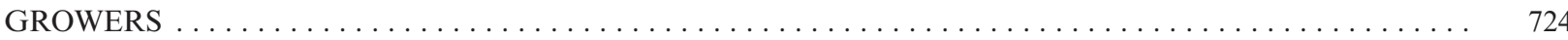

Don Webster DEVELOPMENT OF MARYLAND SHELLFISH AQUACULTURE: A TEN-YEAR ASSESSMENT . . . . 725

Meredith M. White, Allison C. Candelmo, R. Christopher Chambers, Christopher J. Gobler, Andrew L. King,

Nichole N. Price, Richard A. Wahle, Jesica D. Waller BIOLOGICAL RESPONSES OF MULTIPLE NORTHEAST TAXA TO OCEAN ACIDIFICATION

Gary Wikfors NEW INSIGHTS INTO THE DEVELOPMENT AND FUNCTION OF HEMOCYTE TYPES IN OYSTERS 
Kristin Wilson, Jacob Aman, Jeremy Miller, Daniel Belknap EUROPEAN GREEN CRABS IN SOUTHERN MAINE MARSHES: TRENDS IN ABUNDANCE AND MARSH

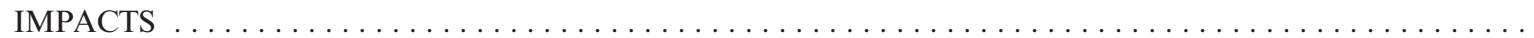

Feng Xu, Saba Ilyas, Jeffrey Hall, Stephen Jones, Vaughn Cooper, Cheryl Whistler GENETIC CHARACTERIZATION OF CLINICAL AND ENVIRONMENTAL VIBRIO PARAHAEMOLYTICUS FROM THE NORTHEASTERN US REVEALS EMERGING RESIDENT AND INVASIVE PATHOGEN

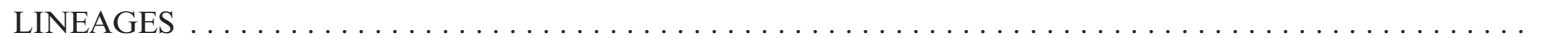

Alan M. Young, James A. Elliott, Mae Taylor, Joseph M. Incatasciato 
COMPARISON OF BOTTOM AND FLOATING GEAR FOR GROWING EASTERN OYSTERS (CRASSOSTREA VIRGINICA) IN SOUTHEASTERN MASSACHUSETTS Abigail F. Archer, Josh Reitsma, Diane Murphy

Cape Cod Cooperative Extension Marine Program \& Woods Hole Sea Grant Program, 3195 Main Street, Barnstable, MA, 02630, USA

During the 2011-2012 growing season the Cape Cod Cooperative Extension Marine Program conducted research in partnership with five shellfish growers from different growing areas on Cape Cod to examine differences between floating gear and bottom gear for growing oysters. The objective of the study was to compare oysters grown in each gear type in terms of average percent survival, daily growth rate, and condition index. For each gear type oysters grown in the top shelves and those grown in the bottom shelves were also examined for differences. Gear and oyster seed were deployed in June 2011 at an initial stocking density of 500 oysters per bag. In spring of 2012 the stocking density was reduced to 150-200 oysters per bag. To estimate percent survival oyster bags were subsampled in May 2012, and in November 2012 - all oysters in the bags were counted. To determine daily growth rate and condition index in November 2012 fifteen oysters from each bag were measured, and five of those were shucked and the meats dried. Pooling the data together from all five sites, mean percent survival was significantly lower in the bottom cages than in the floating cages, the mean daily growth rate of oysters in floating gear was approximately $15 \%$ higher than those grown in bottom gear, and the condition index of oysters grown in floating gear was higher than those grown in bottom gear. Differences were observed among sites illustrating that the floating gear does not perform the same in all growing areas.

ARCTIC SURFCLAM, MACTROMERIS POLYNYMA, CULTURE AT THE DOWNEAST INSTITUTE: EXPLORING METHODS TO DIVERSIFY DOMESTIC SEAFOOD BY CREATING A NEW, FARMED-RAISED BIVALVE

Brian Beal $^{1,2}$, Cody Jourdet ${ }^{2}$, George Protopopescu ${ }^{1,2}$, Kyle Pepperman $^{2}$, Christopher Davis ${ }^{3}$, Sandra Shumway ${ }^{4}$, Kevin Athearn ${ }^{1}$

${ }^{1}$ University of Maine at Machias, 116 O'Brien Avenue, Machias, ME, 04654, USA

${ }^{2}$ Downeast Institute for Applied Marine Research and Education, 39 Wildflower Lane, Beals, ME, 04611, USA

${ }^{3}$ Pemaquid Oyster Company, Inc., P.O. Box 302, Waldoboro, ME, 04572, USA

${ }^{4}$ University of Connecticut, Department of Marine Sciences, 1080 Shennecossett Road, Groton, CT, 06340, USA

The foot of adult Arctic surfclams, Mactromeris polynyma, is prized for its visual and gustatory uniqueness as a sushi and/or sashimi menu item for domestic and Asian dining experiences. In the Northwest Atlantic, this deep-water, shallow-burrowing bivalve is harvested commercially only in the Canadian Maritime Provinces and Quebec (mouth of the St. Lawrence River) by factory ships that use hydraulic dredges to capture individuals and bring them to the surface. Although M. polynyma occurs in the Gulf of Maine, densities are too low to support a commercial fishery. In an attempt to increase the supply, quality, and diversification of domestic seafood, we have begun a multi-year study of the hatchery, nursery, and field-growout parameters of Arctic surfclams with a goal of creating a new culture industry based on whole animals between $1 \frac{1}{1} 2-2$-inches. At the Downeast Institute, broodstock are conditioned at temperatures below $8^{\circ} \mathrm{C}$ over 3-4 months, and larvae reared at $8-10^{\circ} \mathrm{C}$ for $3-4$ weeks. Juveniles ( $>3 \mathrm{~mm}$ ) have attained sizes of $10-12 \mathrm{~mm}$ SL in both surface (floating) and subsurface trays with and without sediment during summer and fall at a nearby protected cove in the town of Beals. As importantly, we have discovered that it is possible to rear post-nursery juveniles to market size in 18-24 months in the lower intertidal (Beals, Machiasport, Cutler) in a wide variety of soft-sediments (mud, muddy sand, sand). The largest single impediment to commercial production to date has been predation by crustaceans, even when deterrent netting is used.

GREEN CRAB, CARINUS MAENAS, WARS IN SOUTHERN MAINE: MANAGING PUBLIC SHELLFISH STOCKS DURING TIMES OF EXPLODING PREDATOR ABUNDANCE Brian Beal $^{1,2}$, Chad Coffin ${ }^{3}$, Clint Goodenow ${ }^{3}$, Sara Randall ${ }^{2}$

${ }^{1}$ University of Maine at Machias, 116 O'Brien Avenue, Machias, ME, 04654, USA

${ }^{2}$ Downeast Institute for Applied Marine Research and Education, 39 Wildflower Lane, Beals, ME, 04611, USA

${ }^{3}$ Stewards of the Sea LLC, 26 Litchfield Road, Freeport, ME, 04032, USA

Although green crabs, Carcinus maenas, have existed in Maine since 1905, their populations have exploded along the Maine coast at least twice since the early 1950's. Both times the increases have been correlated with warming ocean temperatures (1950 1954; 2011-2013). The effect of this invasive species on wild and cultured populations of soft-shell clams, Mya arenaria, was examined during 2013-2014 in and around southern Maine's Harraseeket River, Freeport. A series of manipulative field experiments examined the growth and survival of cultured softshell clam juveniles along with numbers of wild recruits in studies designed to examine the relative efficacy of netting vs. fencing to deter green crab foraging, the combined effect of netting and green crab trapping, and the interactive effects of predator exclusion and presence of clam adults. In addition, the dynamics of green crabs populations were assessed using a series of standard, baited traps in both years in both intertidal and subtidal 
locations along the river. Trapping showed important differences in crab biomass and mean carapace widths between years at all locations. Results of field experiments suggest that site- and season-specific factors play an important role in survival and settling success of soft-shell clams, and that new strategies that incorporate leasing of intertidal flats and/or the implementation of modern municipal intertidal protection requirements should be weighed seriously by coastal communities that co-manage their clam stocks and clamming habitat with Maine's Department of Marine Resources.

ANNUAL CONSISTENCY IN BLUE MUSSEL, MYTILUS EDULIS, SEED PRODUCTION USING HATCHERY METHODS AT THE DOWNEAST INSTITUTE

Brian Beal ${ }^{1,2}$, Kyle Pepperman ${ }^{2}$, George Protopopescu ${ }^{2}$, C. Jourdet ${ }^{2}$, Scott Lindell ${ }^{3}$

${ }^{1}$ University of Maine at Machias, 116 O'Brien Avenue, Machias, ME, 04654, USA

${ }^{2}$ Downeast Institute for Applied Marine Research and Education, 39 Wildflower Lane, Beals, ME, 04611, USA

${ }^{3}$ Marine Biological Laboratory, Woods Hole, MA, 02543, USA

Blue mussel, Mytilus edulis, was the first cultivated bivalve species in Maine, and has been farmed here since the early 1970's. Currently, sixteen sites are approved by Maine's Department of Marine Resources for suspended culture and six sites for bottom culture. Both forms of culturing mussels depend on consistent sources of wild seed that settle onto ropes, nets, or the bottom that originate from poorly understood biotic and abiotic processes affecting both the spawning stock and swimming larvae. Mussels settle onto hard surfaces at sizes of approximately 200-microns $\left(1 / 5^{\text {th }}\right.$ of a millimeter, or $1 / 125^{\text {th }}$ of an inch). Whether or not a farmer has a successful year growing mussels hinges on the many uncontrollable features affecting the early life-history of mussel larvae. Business planning depends on knowing how many animals will be grown to harvest each year; yet, no mussel aquaculturist is able to predict with any accuracy or confidence this basic statistic out beyond the current year, and that is only after the culturist sees what settles onto his/her collector surfaces in the spring/early summer. To reduce the vagaries of wild seed collection, we are beginning to examine methods of culturing blue mussels in a hatchery setting that will allow us to produce seed year-round, settle millions of juveniles (1-2 mm) onto ropes and other surfaces, and grow the animals to sizes of $12-15 \mathrm{~mm}$ in fieldbased nurseries prior to their use by farmers.
INVASIVE EUROPEAN GREEN CRABS: SUDDEN INCREASE IN EROSION POTENTIAL ON SALT MARSHES IN SOUTHERN AND CENTRAL COASTAL MAINE Daniel F. Belknap ${ }^{1}$, Kristin R. Wilson ${ }^{2}$

${ }^{1}$ School of Earth and Climate Sciences, University of Maine, Orono, ME, 04469-5790, USA

${ }^{2}$ Wells National Estuarine Research Reserve, 342 Laudholm Road, Wells, ME, 03820, USA

The Maine coast has experienced an explosive population growth of the invasive European Green Crab (Carcinus maenus), which started in 2012. Green crabs are causing widespread destruction of juvenile clams, eelgrass beds, with critical consequences for ecosystems. In 2013 we noticed severe dieback of low salt marshes in the Damariscotta River Estuary, later observed in many localities along the southern Maine coast. Green crabs caused the widespread clipping of Spartina alterniflora low-marsh grass, denuding the surface and increasing surficial erosion. Teeming hordes of crabs were observed burrowing into peat banks, increasing calving of peat-bank flaps and increasing erosional retreat. Salt marshes are critical in the bluff erosion/ stability cycle. Rapid dieback and consequent marsh erosion could lead to greater bluff erosion and land loss. After a cold winter in 2013-2014, the extent of low-marsh clipping was much reduced. Using Maine Sea Grant, Casco Bay Estuary Partnership and other funding, we have installed 8 stations in 3 estuaries in southern and central coastal Maine to monitor horizontal marsh peat-bluff retreat (stake arrays) and deposition/erosion rates on marsh surfaces (SET - surface elevation transects). Preliminary data show expected seasonal accumulation on the SET's, which we anticipate will be reduced over the winter. Peat bluff retreat rates have been inconclusive over the summer, but we anticipate increases over the winter. These stations serve as long-term monitoring baselines. This geological study is coupled with investigation of the crab population densities, through netting and trapping, and direct study of crab burrows through coring and CT scans.

AQUACULTURE AND THE RHODE ISLAND SHELLFISH MANAGEMENT PLAN

David Beutel $^{1}$, Azure Cygler ${ }^{1}$, Monique LaFrance ${ }^{2}$, Dale Leavitt ${ }^{3}$, Jennifer McCann ${ }^{1}$, Jeff Mercer ${ }^{2}$

${ }^{1}$ Rhode Island Sea Grant, University of Rhode Island, South Ferry Road Narragansett, RI, 02882, USA

${ }^{2}$ Graduate School of Oceanography, University of Rhode Island, South Ferry Road Narragansett, RI, 02882, USA

${ }^{3}$ Roger Williams University, One Old Ferry Road, Bristol, RI, 02809, USA

In January 2013, Rhode Island started the process to create the state's first comprehensive shellfish management plan (SMP). With URI's Coastal Resources Center facilitating the effort, 
a stakeholder-driven process ensued, bringing together vested parties from the state management agencies, the wild harvest shellfish industry, the shellfish restoration community, and growing aquaculture industry, as well as recreational diggers, researchers, and concerned citizens. The crux of the process was to create a set of management recommendations for the resource and associated industries that would honor and enhance existing activities through a transparent process that builds upon and incorporates best science, through an adaptive management framework. The plan culminated in November 2014, with the following year dedicated to creating an Implementation Plan and Research Agenda for the management recommendations, as well as improved marketing of shellfish. Some early actions of the SMP focused on the aquaculture industry: 1) Creating and Implementing a Vibrio Control Plan for oysters in 2014, using the industry template of proactive controls and making the state's Division of Agriculture as the lead. 2) Cross-agency participation in upweller and lease inspections. 3) Overall aquaculture regulation reform to simplify and streamline the process for industry, consisting of transfer of much authority from R.I. Department of Environmental Management (RI DEM) to Coastal Resources Management Council (CRMC). These actions were achieved through collaborative decision-making between RI DEM (charged with managing wild shellfish resources), CRMC (overseeing aquaculture leasing), and the aquaculture industry - An example of the positive change assisted by the SMP process.

NORTHWEST ATLANTIC POPULATION STRUCTURE AND GENE FLOW IN THE GREEN CRAB: AN UPDATE ON THE CRAB'S DYNAMIC INVASION FRONT

April Blakeslee ${ }^{1}$, Joe Roman ${ }^{2}$

${ }^{1}$ Biology Department, Long Island University-Post, 720

Northern Blvd., Brookville, NY, 11548, USA

${ }^{2}$ Gund Institute for Ecological Economics, University of Vermont, Burlington, VT, 05405, USA

The European green crab (Carcinus maenas) is one of the most notorious marine invaders globally — established on nearly every continent on Earth but native to just one. In eastern North America, C. maenas has had two major introduction events - the first represents a historical invasion in the 1800 s that introduced western European genotypes to the US, which expanded northwards, eventually reaching Atlantic Canada about 100 years later. The second cryptic invasion likely occurred in the 1980s1990s, introducing novel northern European genotypes to eastern Atlantic Canada, which then began to spread through the region, especially with the mean flow of currents to the southwest. Not only did this new introduction lessen the genetic bottleneck in the region, but it also lead to admixture of genotypes from the two invasions along the Scotian shelf. Several of those admixed genotypes were recently transported to Newfoundland, likely via ballast water originating in the central/western Scotian shelf. Moreover, this admixture zone has spread further southwest and northeast over time, representing a highly dynamic system. Here, we update the present understanding of this system, adding mitochondrial sequence data from 2013-2014 to the 15 year historical dataset. We find that the invasion front of admixed genotypes has continued to expand southwestwards, reaching new locations and with greater frequencies for the novel northern genotypes in regions of northeast US and western Atlantic Canada as predicted by models of its spread. Continued monitoring of this dynamic system is important for better understanding the crab's overall impact in the region.

SEDIMENT FLUX MODELING OF BIVALVE AQUACULTURE SPATIAL IMPACTS ON SEDIMENTS (BASIS)

Damian C. Brady ${ }^{1}$, Jeremy M. Testa ${ }^{2}$, Jeff C. Cornwell ${ }^{3}$, Mike S. Owens $^{3}$, Larry P. Sanford ${ }^{3}$, Roger I. E. Newell ${ }^{3}$, Carter R. Newell $^{4}$, John Richardson ${ }^{5}$, Steve E. Suttles ${ }^{3,6}$

${ }^{1}$ Chesapeake Biological Laboratory, University of Maryland Center for Environmental Science, P.O. Box 38, Solomons, MD, 20688, USA

${ }^{2}$ School of Marine Sciences, University of Maine, 193 Clark Cove Road Walpole, ME, 04573, USA

${ }^{3}$ Horn Point Laboratory, University of Maryland Center for Environmental Science, 2020 Horns Point Road, Cambridge, MD, 20613, USA

${ }^{4}$ Pemaquid Mussel Farms, P.O. Box 1255, Damariscotta, ME, 04543, USA

${ }^{5}$ Blue Hill Hydraulics, 447 Falls Bridge Road, Blue Hill, ME, 04614, USA

${ }^{6}$ United States Geological Survey, Woods Hole Science Center, 384 Woods Hole Road, Quissett Campus, Woods Hole, MA, 02543, USA

Bivalve aquaculture relies on naturally occurring phytoplankton and detritus as food sources, thereby avoiding external nutrient inputs associated with finfish aquaculture. However, high filtration rates and concentrated biomass of bivalves focus intense particle deposition on surrounding sediments, with potentially adverse environmental impacts. Estimating this depositional flux is notoriously difficult due to methodological constraints and dynamic processes such as resuspension and advection. This study used a pattern search algorithm and a mechanistic sediment flux model to estimate seasonal particulate organic carbon deposition in the vicinity of an eastern oyster farm in the lower Choptank River, MD, USA. The model is the standalone version of the two-layer sediment flux model (SFM) 
currently implemented for Chesapeake Bay TMDL management. The pattern search algorithm tunes the depositional flux to fit ammonium flux at a transect of sites from the farm to a control site in the open estuary. Subsequently, modeled sediment-water fluxes were compared to observed denitrification rates and nitrate fluxes. Thus, this method calculates the aerobic layer depth and integrated measures of nitrogen cycling as a function of seasonal farm dynamics. Model derived estimates of biodeposition were compared with sediment trap estimates as well as estimates from a particle tracking algorithm in a fine scale hydrodynamic model that accounts for tidal flows and wind-waves. Large differences between modeled and sediment trap derived estimates highlight the role of sediment erodability and episodic events in transporting biodeposits away from this particular farm, resulting in a diminished local environmental impact.

POTENTIAL USE OF THE INVASIVE EUROPEAN GREEN CRAB (CARCINUS MAENAS) AS AN INGREDIENT IN ATLANTIC SALMON (SALMO SALAR) DIETS; A PRELIMINARY ANALYSIS

Gary Burr, William Wolters

USDA ARS National Cold Water Marine Aquaculture Center, 25 Salmon Farm Road, Franklin, ME, 04634, USA

Atlantic salmon (Salmo salar) is an important cultured carnivorous species with wide consumer acceptance. With the finite supply of available fishmeal and fish oil available for aquafeeds, research on and utilization of alternative protein and lipid sources is expanding. We examined the nutritional profile of deshelled green crab, both muscle tissue and gastrointestinal tract. Generally green crabs have high levels of protein (around $83 \%$ on a dry basis) and low lipid levels (1.2\% on a dry basis) and high moisture levels $(\sim 80+\%)$. The major concern is the high ash content in the gastrointestinal tract $(21.3 \%)$, which could be sand that the crabs have consumed. The amino acid profile is acceptable for use in salmonid feeds and can be combined with other ingredients to provide optimal amino acid levels for growth. Green crab lipids are high in both eicosapentaenoic acid (EPA, 20:5 n-3) and docosahexaenoic acid (DHA, 22:6n-3), but this is of limited value due to the low overall lipid content of the crabs. Future studies will be need to optimize the extraction of shell from the soft tissue, removal of the possible sand from the GI tract material and feeding trials to determine the acceptable levels for use in aquafeeds.

\section{AN INTEGRATED ECOLOGICAL-ECONOMIC MODELING FRAMEWORK FOR THE SUSTAINABLE MANAGEMENT OF OYSTER FARMING}

Carrie J. Byron ${ }^{1}$, Di Jin², Tracey M. Dalton ${ }^{3}$

${ }^{1}$ Marine Sciences Department, University of New England, 11 Hills Beach Road, Biddeford, ME, 04005, USA

${ }^{2}$ Marine Policy Center, Woods Hole Oceanographic Institution, 266 Woods Hole Road, Woods Hole, MA, 02543, USA

${ }^{3}$ Department of Marine Affairs, University of Rhode Island, 1 Greenhouse Road, Kingston, RI, 02281, USA

Sustainable resource management requires improved understanding of complex ecological processes and the socioeconomic drivers shaping human-environment interactions. To better understand complex interconnections among ecological and economic systems, this study integrates a coastal marine ecosystem model with a model of the associated coastal economy. Through simulations of different ecological and socioeconomic scenarios, the integrated model can be used to generate predictive ecological and economic values for policy analysis, providing an opportunity for more rational and informed debate concerning sustainable marine resource development. To demonstrate utility of this integrated model, it was applied to coastal shellfish aquaculture production in Narragansett Bay, Rhode Island, US, a coastal ecological-economic system that provides important ecosystem services and contributes to the regional economy.

\section{EFFECT OF INTERTIDAL EXPOSURE ON VIBRIO PARAHAEMOLYTICUS LEVELS IN DELAWARE BAY OYSTERS}

Lisa Calvo, Tal Ben-Horin, David Bushek

Haskin Shellfish Research Laboratory, Rutgers University, 6959 Miller Avenue, Port Norris, NJ, 08349, USA

Oyster grounds located along the extensive intertidal sand flats of the Delaware Bay Cape Shore region support an emerging and productive aquaculture industry. Here, oysters experience moderate to high salinity and are exposed twice daily during low tide. Previous studies from the Pacific Northwest indicated that intertidal exposure can accelerate the proliferation of vibrios, common estuarine bacteria responsible for sporadic cases of illness associated with the consumption of raw or undercooked shellfish. To evaluate whether this result applies to the mid-Atlantic, we conducted a preliminary study testing whether levels of total and pathogenic Vibrio parahaemolyticus $(\mathrm{Vp})$ differ between oysters cultivated intertidally and subtidally along the Delaware Bay Cape Shore. We did not find significant differences in levels of total and pathogenic Vp between subtidal and intertidal oysters, nor did we see a significant increase in vibrio burdens over a time course of intertidal exposure. This initial result suggests that the relationship between intertidal environmental conditions and vibrio levels in harvested oysters is not as straightforward as previously thought. Locally relevant harvest and management practices are required to minimize the risk of vibrio illness. 
TREATMENTS TO ERADICATE INVASIVE TUNICATE FOULING FROM BLUE MUSSEL SEED AND AQUACULTURE BAGS

Mary R. Carman ${ }^{1}$, Scott Lindell ${ }^{2}$, Emma Green-Beach ${ }^{2}$, Victoria R. Starczak $^{1}$

${ }^{1}$ Woods Hole Oceanographic Institution, Woods Hole, MA, 02543, USA

${ }^{2}$ Marine Biological Laboratory, Woods Hole, MA, 02543, USA

In New England and elsewhere, invasive species of colonial tunicates commonly foul wild and cultured blue mussels and aquaculture gear. Eco-friendly experimental treatments were selected for trial application with the intention of destroying tunicates without causing significant mortality to mussel seed, compared to controls. Chemical (acetic acid) and water (brine and freshwater) treatments were applied short-term and longterm to juvenile mussels with and without the presence of tunicates. Acetic acid baths were lethal to tunicates and juvenile mussels. Brine baths killed tunicates but less mussel death occurred in the short-term brine bath. Both long-term and short-term freshwater baths were effective against tunicates but less mussel death occurred in the short-term bath. Tunicates survived short-term freshwater sprays and not long-term freshwater sprays, however, long-term freshwater sprays were slightly more lethal to mussels than short-term freshwater sprays. With these results, freshwater baths are the recommended method to eradicate colonial tunicates from mussel seed and aquaculture gear.

\section{DETECTION OF BIVALVE MOLLUSC PATHOGENS: ARE WE HEADING IN THE RIGHT DIRECTION? \\ Ryan Carnegie}

Department of Aquatic Health Sciences, Virginia Institute of Marine Science, College of William \& Mary, Route 1208 Greate Road, Gloucester Point, VA, 23062, USA

North American laboratories remain leaders in the development and application of diagnostics for shellfish pathogens. So what's the problem? The World Organisation for Animal Health (OIE) has begun to cast a critical eye over the state of diagnostics for pathogens of concern as well as the laboratories that perform them. A look at the diagnostic methods for shellfish diseases reveals a continued proliferation of molecular diagnostic tools but with infrequent attempts to perform basic assessments of the performance of these assays. Full validations are essentially nonexistent. The OIE expects that laboratories themselves be accredited to the ISO 17025 or equivalent level for quality management, yet few of our laboratories can claim this level of accreditation. We should be concerned, individually and collectively, that at some point in the near future our ability to provide a trustworthy product may be questioned. The solution to this may lie in part in a more determined focus on assessment and validation of assays, in greater standardization of the tools in use, and in the regular use of proficiency tests and training to ensure laboratory competence. Accreditation of laboratories performing diagnoses in the service of national and international health management, as opposed to research, will eventually be a must. Beyond this, we should more actively engage in educating the next generation of diagnosticians and researchers in shellfish health, including in the microscopic observation of pathology and parasitology. As senior scientists in the field continue to retire this is at risk of becoming a lost art.

\section{INTRACELLULAR PH IN BIVALVE HEMOCYTES AND} RESPONSES TO IN VITRO ACID CHALLENGE April Croxton, Gary Wikfors

NOAA/NMFS, Northeast Fisheries Science Center, Milford Laboratory, 212 Rogers Avenue, Milford, CT, 06460, USA

Lowered $\mathrm{pH}$ levels in oceanic and estuarine systems have caused great concern for the future adaptability of mollusc species. Vulnerability of bivalve species to decreasing $\mathrm{pH}$ levels will depend upon their ability to maintain homeostasis as external conditions change. The objective of this study was to measure the intracellular $\mathrm{pH}\left(\mathrm{pH}_{\mathrm{i}}\right)$ of hemocytes, as representative cells, of several molluscan species and to determine the rate of recovery of $\mathrm{pH}_{\mathrm{i}}$ following in vitro exposure to acidified conditions. Intracellular $\mathrm{pH}$ of hemocytes from several estuarine bivalve species (bay scallop, blue mussel, eastern oyster, northern quahog, and softshell clam) and an oceanic species (surf clam) were determined using fluorescent SNARF probes and flow cytometry. Hemocyte $\mathrm{pH}_{\mathrm{i}}$ of these species ranged from 7.0-7.5, with the oceanic surf clam well within this range. $\mathrm{Rapid}_{\mathrm{pH}} \mathrm{H}_{\mathrm{i}}$ recovery rates of estuarine species indicate widespread ability to maintain homeostasis when challenged with extracellular acidification. Recovery time for hemocytes of the surf clam was longer than for estuarine species, suggesting that estuarine species may be more adaptable than oceanic bivalves. These results indicate the need for further analysis of additional marine species to be able to provide better understanding of the physiological responses of bivalves to acidifying environments. 
EPIZOOTIOLOGICAL ANALYSIS OF QPX DISEASE DATA FROM HARD CLAM (AKA QUAHOG) MONITORING IN AN ENZOOTIC ESTUARY

Soren F. Dahl' ${ }^{1}$, Debra Barnes ${ }^{2}$, Wade Carden ${ }^{2}$, Bassem Allam ${ }^{1}$

${ }^{1}$ School of Marine and Atmospheric Sciences, Stony Brook University, Stony Brook, NY, 11794, USA

${ }^{2}$ Bureau of Marine Resources, New York State Department of Environmental Conservation, East Setauket, NY, 11733, USA

Since the 2002 discovery of hard clams (Mercenaria mercenaria) dying from QPX disease in Raritan Bay (NY), the Bureau of Marine Resources, New York State Department of Environmental Conservation (NYSDEC), has developed a partnership with Stony Brook University's Marine Animal Disease Lab (MADL), School of Marine and Atmospheric Sciences, to monitor the microbial (protist) pathogen QPX. Hard clam histological and molecular diagnostics from this program have been compiled with environmental measurements, creating a unique data set that is being analyzed for a better understanding of the basic ecology and epizootiology of this infectious disease. Infection seasonality is evident across the time series, with summer peaks that have shifted earlier in the year toward late spring. Monitoring stations across the estuary reveal that some fishery areas are virtually unaffected by QPX disease. These areas are characterized with lower salinities, which is common with other microbial infections afflicting marine bivalves, but uncommon dynamics are observed with the least infected clam areas having the highest summer temperatures. Experimental QPX studies conducted by the MADL provide supportive insight regarding environmental relationships with QPX disease dynamics. Analysis of hard clam cofactors shows no difference in infection according to gender but there is a difference in size, with infected clams being a little smaller on average, and there is a significant positive relationship of clam density with infection.

\section{WILL CLIMATE CHANGE HELP NEW YORK HARD} CLAMS FIGHT DISEASE?

Soren F. Dahl, Bassem Allam

School of Marine and Atmospheric Sciences, Stony Brook University, Stony Brook, NY, 11794, USA

In projections of climate change for the Northeastern US, warming trends will progress along with increased precipitation, particularly during winter and spring. Hard clams suffered significantly from QPX disease under cool water $\left(13^{\circ} \mathrm{C}\right)$ laboratory treatments compared to warm water treatments $\left(21^{\circ} \mathrm{C}\right.$ and $27^{\circ} \mathrm{C}$ ). Coastal New York (NY) waters are expected to experience more days of temperatures above $21^{\circ} \mathrm{C}$. QPX related hard clam mortalities in the lab were greater under high (30ppt) versus low (17ppt) salinity treatments and in vitro studies have shown QPX growth to be inhibited by low salinities. Increased precipitation to watersheds and heavier river flow will alter estuarine salinity regimes that could restrict the distribution of QPX in hard clam habitats. Analysis of field monitoring data from an enzootic NY estuary reveal areas of lower salinity and higher summer temperatures have limited QPX infections. Climate change is often considered a source of potential stressors to marine organisms that increases their susceptibility to physiological ailments and opportunistic disease. In this particular scenario of QPX disease in NY coastal waters, climate change may become more detrimental to this specific opportunistic pathogen and benefit the health of hard clam populations.

\section{RECENT DEVELOPMENTS IN PURPLE-HINGED ROCK SCALLOP CULTURE ON THE US WEST COAST \\ Jonathan P. Davis}

Taylor Shellfish Farms, Inc., 701 Broad Spit Road, Quilcene, WA, 98376, USA

There is a strong desire to develop native species for aquaculture development to diversify the shellfish industry, help alleviate production declines associated with oyster seed shortages, and avoid concerns often voiced today about the use of non-native species. The purple-hinged rock scallop (Crassadoma giganteus) is a large scallop native to the North American west coast from Alaska to Baja, California. It's large adductor muscle, rapid growth, and wide natural distribution makes it an excellent candidate for culture, especially in the southerly portion of its range. The goals of a four-year USDA funded project to help establish purple-hinged rock scallop culture on the US west coast is to expand the west coast shellfish industry through creation of triploid seed and demonstration of efficient culture methods for this native scallop. Results to date include the production of diploid and triploid seed with growth trials for both ploidies poised to start early in 2015. A viable shellfish industry in the United States is critical to maintain rural economies that are dependent on marine resource development and working waterfronts and scallop culture can contribute to the range of species presently in aquaculture production. Larval, seed and juvenile growout techniques are under development; larval scallops are amenable to standard rearing techniques so long as diatoms (Chaetoceros spp.) and the red algae, (Rhodomonas salina) are included in the diet. Juvenile growout is sensitive to density with scallops growing rapidly at 400 scallops per $\mathrm{M}^{2}$; optimal conditions in north Puget Sound. 
PRELIMINARY RESULTS GENERATED BY MTI CIP 163 'UNDER-UTILIZED SHELLFISH PRODUCTS WITH EMPHASIS ON GREEN CRAB"

\section{John der Kinderen}

WNWN LLC, 918 Alfred Road, Arundel, ME, 04046, USA

The ongoing feasibility study supported by a Maine Technology Institute cluster grant is beginning to yield some preliminary results. The primary focus of this grant has been to identify potential uses/markets for green crab and other underutilized shellfish and to explore how those markets might be translated into new economic activity. Emphasis has been on green crab due to the negative economic impact it has had on the bivalve industry and the pressure it has exerted on coastline ecology. The study has so far revealed various economic uses for green crab which, although encouraging, require more study. Among these uses, the most promising are 1) human consumption made possible by new processing equipment, 2) production of animal feed ingredients (fish meal and oil substitute), 3) production of chitin, chitosan, and derivative products and 4) integrated utilization where all of the above products can be generated through a single process. There is much greater consumption demand for crab (including small crabs) in Asia than there is in the U.S. There is active exploration of the economic potential of the Asian markets, not only for green crab but other species as well.

CONNECTICUT'S VIBRIO PARAHAEMOLYTICUS CONTROL PLAN AND MONITORING PROGRAM

Kristin DeRosia-Banick, David Carey, Joseph DeCrescenzo

Connecticut Department of Agriculture Bureau of Aquaculture, 190 Rogers Ave., Milford, CT, 06460, USA

Vibrio parahaemolyticus is a naturally occurring marine bacterium in the same family as those that cause cholera and Vibrio vulnificus infection. This bacterium lives in brackish saltwater and causes gastrointestinal illness in humans. Prior to 2012, Vibrio parahaemolyticus typically caused sporadic foodborne illnesses related to raw molluscan shellfish consumption in the Northeast region of the US. In 2013, the state of Connecticut closed harvest areas associated with illnesses from August 2 to September 17. Illnesses were subsequently determined by serotyping of clinical isolates to be linked to a specific virulent strain of Vibrio parahaemolyticus. During 2014, Connecticut's Vibrio parahaemolyticus control program managers worked with industry to incorporate more stringent time to temperature requirements in order to minimize the proliferation of this virulent strain of bacteria, and reduce the risk of consumer illness associated with molluscan shellfish. In order to gain a better understanding of Vibrio parahaemolyticus levels and their relevance to implementing meaningful Vibrio controls in Connecticut growing waters, Connecticut's Vibrio parahaemolyticus monitoring plan includes the collection of environmental parameters such as water temperature, air temperature, salinity and depth that may correlate to levels of Vibrio bacteria in shellfish. In addition, post-harvest time and temperature controls currently in place as required by Connecticut's Vibrio parahaemolyticus Control Plans are evaluated by using continuous temperature data loggers to determine the effectiveness of post-harvest temperature controls and correlating these controls to quantifiable impacts on Vibrio levels in shellfish and the associated risk of consumer illness.

DIRECT MEASUREMENTS OF THE NUTRIENT MANAGEMENT POTENTIAL OF RIBBED MUSSELS, GEUKENSIA DEMISSA, AT TWO SITES IN UPPER NARRAGANSETT BAY, RHODE ISLAND

Mark S. Dixon ${ }^{1}$, Genevieve Bernatchez ${ }^{2}$, Eve Galimany ${ }^{3}$, Judy Yaqin Li ${ }^{1}$, Shannon L. Meseck ${ }^{1}$, Julie M. Rose ${ }^{1}$, Gary H. Wikfors ${ }^{1}$

${ }^{1}$ NOAA/NMFS, Northeast Fisheries Science Center, Milford Laboratory, 212 Rogers Avenue, Milford, CT, 06460, USA

${ }^{2}$ Department of Ecology and Evolutionary Biology, 321 Steinhaus Hall, University of California, Irvine, CA, 92697, USA

${ }^{3}$ Institut de Ciències del Mar (CSIC), PasseigMarítim de la Barceloneta, 37-49, 08003 Barcelona, Spain, and IEO-Centre Oceanogràfic de les Balears, Moll de Ponent s/n, Palma 07015, Spain

There is growing interest in the ability of suspension-feeding bivalve shellfish to filter and assimilate organic matter in seston, thereby removing nutrients from eutrophic coastal waters. The term "nutrient bioextraction" has been coined to identify this ecosystem service. Accurate measurements of clearance and assimilation are needed to estimate the potential of bivalves to contribute to water quality and nutrient management. The ribbed mussel, Geukensia demissa, is capable of filtering a wide size-range of particles, has shown adaptability to a broad range of habitats, and has exhibited high organic-matter assimilation efficiency. Results from previous studies, however, have shown site-specific variability in the capacity of mussels to assimilate nutrients. The need for site-specific testing is evident. Two sites in Narragansett Bay, Rhode Island were selected for the current study. The biodeposition method, coupled with water quality measurements, was used to quantify filtration and assimilation of ribbed mussels at each site monthly from June through September 2014. Total particulate matter and percent organic were higher, $8.12 \mathrm{mg} / \mathrm{L}$ and 59\%, respectively, at Field's Point in the Providence River than at Greenwich Bay in the upper bay, $6.80 \mathrm{mg} / \mathrm{L}$ and $48 \%$, respectively. Mussels had a lower clearance rate at Field's Point, $0.98 \mathrm{~L} /$ hour but higher assimilation rate, $2.12 \mathrm{mg} /$ hour, compared to Greenwich Bay, $1.76 \mathrm{~L} /$ hour and $0.97 \mathrm{mg} /$ hour. Mussels in Field's Point had higher absorption efficiency $56 \%$ versus $38 \%$ in Greenwich Bay. Results indicate that ribbed mussel bioextraction would be more effective at the more eutrophic Field's Point site than in Greenwich Bay. 
TWO POTENTIAL PASSIVE ANTI-PREDATOR TECHNIQUES FOR LONGLINE MUSSEL CULTURE Marcel Fréchette ${ }^{1}$, Éric Bujold ${ }^{2}$

${ }^{1} 1200 \mathrm{du}$ Sanatorium, Mont-Joli, QC, G5H 3V9, Canada

${ }^{2}$ Ferme Maricole du Grand Large, 583 boul. Perron, Carleton-sur-mer, QC, G0C 1G0, Canada

Near Carleton-sur-Mer, Québec, mussels are left on spat collectors and grown profitably on longlines without density adjustment. Duck predation, however, has been a growing problem in the recent years, causing up to $95 \%$ reduction of mussel spat biomass. Active anti-predator techniques appear inefficient. Therefore we focussed on developing passive duckcontrol methods. The first protective device reported here is made of a top steel ring and a lower steel ring connected by $3 \mathrm{~m}$ long collector ropes. Once spat collection is complete the rings and collectors are placed within a netting bag. The resulting cylindrical cage is immersed for the rest of the culture cycle. After two migratory episodes biomass was reduced by only $20 \%$. An improved version of these modular cages is being tested to ensure that they are totally innocuous for ducks. The second method currently being tested is based on the use of knots of the type of the chain sinnet. Knots add structural complexity to spat collectors and therefore may provide anti-predator spatial refuges to spat just as crevices in natural settings do. A critical characteristic of the different potential knots is that they be easily undone at harvesting. Early results of an ongoing experiment using the chain sinnet suggests that the presence of knots increases spat collection. So far, however, the anti-predator effect of the knot presently tested is negligible. The experiment will be pursued for two more years in order to study a complete production cycle. Other knot types will be tested in the near future.

CLEARANCE RATE REGULATION IN MUSSELS: ADDING THE EFFECT OF ORGANIC SESTON LEVEL TO A MODEL OF INTERNAL STATE-BASED REGULATION

M. Fréchette ${ }^{1}$, J. M. Urquiza ${ }^{2}$, G. Daigle ${ }^{2}$, D. Rioux-Gagnon ${ }^{2}$

${ }^{1}$ Ministère des Pêches et des Océans, Institut MauriceLamontagne, 850 Route de la Mer, Mont-Joli, Québec, CP. 1000, G5H $3 Z 4$ Canada

${ }^{2}$ Département de Mathématiques et de Statistique, Faculté des sciences et de génie, Pavillon Alexandre-Vachon, Université Laval, Québec, QC, G1V 0A6 Canada

Dynamic energy budget simulations of mussel clearance rate based on an internal state feeding module (ISFM) provide better results than when based on an externally (e.g.: phytoplankton concentration) regulated model (Fréchette 2012 J. Mar. Sci. 73:32-40). We report an experiment designed to test ISFM.
Mussels were grown along a natural seston gradient in the lab. According to ISFM, differences in energy reserves would cause differences in clearance rate along the food gradient. We found no significant effects of the food gradient on clearance rate. However, we found significant effects of time at all time scales studied tens of minutes, hours, days. We focussed on hourly averages of clearance rate and extended the initial ISFM model to include the effect of phytoplankton level. We found an excellent fit between the model and the data. Thus, although the present experiment was inconclusive with respect to bioenergetics, the extended ISFM model provided a solid framework for modelling hourly mean clearance rates. This is strong indirect evidence in support of the extended ISFM model. This adds to the evidence found in the literature, which supports the bioenergetics part of the model. We conclude that feeding modules of simulation models should be based on ISFM.

\section{THE CONNECTICUT SHELLFISH INITIATIVE: BUILDING ON THE PAST AND CREATING A VISION FOR THE FUTURE \\ Tessa Getchis ${ }^{1}$, Nancy Balcom ${ }^{1}$, Anoushka Concepcion ${ }^{1}$, Sylvain De Guise ${ }^{1}$, Julie Rose ${ }^{2}$ \\ ${ }^{1}$ Connecticut Sea Grant, University of Connecticut, Groton,} CT, 06340, USA

${ }^{2}$ NOAA/NMFS, Northeast Fisheries Science Center, Milford Laboratory, 212 Rogers Avenue, Milford, CT, 06460, USA

Shellfish are an important ecological, economic and recreational resource to Connecticut citizens. While there is considerable opportunity and growth in the various shellfish sectors, significant challenges exist and risk is pervasive. Lack of formal communication avenues and potential conflicts among industry, regulators, municipal officials and other shellfish stakeholder groups have limited much-needed collaboration to deal with emerging environmental and economic threats. In response to these challenges, Connecticut Sea Grant (CTSG) in collaboration with NOAA National Marine Fisheries Service Milford Laboratory convened meetings with shellfish interest groups and citizens across the State and proposed the development of a vision plan for the future of Connecticut shellfisheries and natural shellfish resources. Modeled after the NOAA National Shellfish Initiative, the Connecticut Shellfish Initiative is a stakeholder-driven effort to map out a vision for the future of Connecticut shellfish resources. The plan, now in development, will document the importance of the various shellfish sectors, identify and characterize issues of importance to Connecticut shellfish stakeholders and citizens and will establishes specific and time bound goals, objectives and actions to be taken. To learn more, visit: http:// shellfish.uconn.edu. 
SKULKING BEHIND AN MSX SMOKESCREEN: SSO PREVALENCE IN MAINE AND MASSACHUSETTS Cem Giray ${ }^{1}$, Diane Murphy ${ }^{2}$, Marcy L. Nelson ${ }^{3}$

${ }^{1}$ Kennebec River Biosciences Inc., 41 Main Street, Richmond, ME, 04357, USA

${ }^{2}$ Cape Cod Coop Ext \& Woods Hole Sea Grant, Box 367, Barnstable, MA, 02630, USA

${ }^{3}$ Marcy L. Nelson, Maine Department of Marine Resources, PO Box 8, 194 McKown Point Road, West Boothbay Harbor, ME, 04575, USA

Haplosporidium costale (SSO) has been reported in US oysters since the 1980's from Maryland to as far north as Maine. However, in part due to the relatively low level of mortality reported in association with its detection in more recent years, this organism is often overlooked in routine testing and due to the potential for high level of associated mortality, regulatory testing has typically targeted another Haplosporidian, H. nelsoni (MSX). Testing conducted in Maine and Massachusetts since 2010 indicates varying prevalence of SSO in wild and farmed populations of the eastern oyster (Crassostrea virginica). In rare cases SSO detection was also associated with disease and mortalities; in some cases SSO was present solo, while in others in co-occurrence with MSX and/or Perkinsus marinus. SSO prevalence, co-occurrence with MSX, detection via PCR versus histology, relationship with any mortalities, and shifts in presence of MSX versus SSO in farmed and wild $C$. virginica and potential relationship with the use of MSX-resistant $C$. virginica in aquaculture are investigated.

\section{VIBRIO PARAHAEMOL YTICUS PREVALENCE IN MAINE} OYSTERS

Cem Giray $^{1}$, Victoria Bowie ${ }^{1}$, Christopher Davis ${ }^{2}$, William Mook ${ }^{3}$

${ }^{1}$ Kennebec River Biosciences Inc., 41 Main Street, Richmond, ME, 04357, USA

${ }^{2}$ Pemaquid Oyster Company Inc., PO Box 302, Waldoboro, ME, 04572, USA

${ }^{3}$ Mook Sea Farm, 321 State Rte. 129, Walpole, ME, 04573, USA

Vibrio parahaemolyticus associated with bivalve shellfish has in recent years become a major concern in southern New England states, but limited information was available with regards to its presence in Maine. Previously, this organism had shown rare occurrence in Maine and the majority of isolates had been composed of non-pathogenic strains. Collaborative work was performed during 2014 by Kennebec River Biosciences (KRB), Mook Sea Farm (MSF) and Pemaquid Oyster Company (POC) to examine the occurrence of this organism in Damariscotta River oysters. Findings by bacterial culture and molecular testing showed intermittent $V$. parahaemolyticus presence in grow-out oysters from several sites. Isolates were identified by biochemical and DNA sequence analyses, and evaluated for presence of genes associated with pathogenicity. Results were used by MSF and POC to conduct voluntarily established harvest, handling and monitoring practices and minimize any potential effect of this organism on their market product. Further work, funded by the Maine Aquaculture Innovation Center, is planned for 2015 to screen oysters from additional Maine river systems in order to gain a better understanding of $V$. parahaemolyticus presence in Maine, determine pathogenicity of detected strains and provide growers data on any $V$. parahaemolyticus presence in their growout area and help them assess the efficacy of their harvest biosecurity protocols.

\section{SUMMARIZING MILFORD LABORATORY'S RESEARCH ON THE ECOLOGICAL EFFECTS OF HYDRAULIC DREDGING, AS USED IN CLAM CULTIVATION IN LONG ISLAND SOUND}

Ronald Goldberg, Julie M. Rose, Renee Mercaldo-Allen, Shannon L. Meseck

NOAA/NMFS, Northeast Fisheries Science Center, Milford Laboratory, 212 Rogers Avenue, Milford, CT, 06460, USA

Aquacultural cultivation of northern quahogs (Mercenaria mercenaria) in Long Island Sound (LIS) is conducted on leased beds and relies on natural recruitment. Harvest is accomplished by using hydraulic dredges that pump seawater under pressure into sediment to loosen clams, which are then retained by the dredge. The shellfish industry and managers requested an assessment of dredge harvest on marine habitat. We conducted a literature review of the ecological effects of dredging, considering physical, biological, and chemical impacts. Much of the literature was specific to either navigational dredging or to harvest fisheries, where continual dredging is conducted by many, seeking a common resource on common grounds. The review indicated that dredging impacts vary with harvest practice, sediment type, season, location, biological community, and many other factors. We then conducted several years of field experiments to address the effects of dredging on benthic habitat. In all experiments the benthic community and sediment chemistry were assessed on a weekly basis over several months. We found that seasonality and sediment grain size had greater effect on benthic communities than the impacts of dredging. Some impacts to sediment chemistry were observed post-dredging, but these disappeared within a few weeks. In one experiment we found significantly more newly-settled hard clams on plots that had been dredged, compared to non-dredged plots. Near-shore ecosystems are dynamic and are inhabited by assemblages that are resilient to natural disturbance. Farming practices typical of LIS appear to have minimal and short-lived effects on habitat, biota, and sediment chemistry. 
PERFORMANCE OF SELECTIVELY-BRED LINES OF EASTERN OYSTERS, CRASSOSTREA VIRGINICA, AT DIFFERENT LOCATIONS ALONG THE EAST COAST OF THE UNITED STATES

Marta Gomez-Chiarri ${ }^{1}$, Dina Proestou ${ }^{2}$, Ryan Corbett ${ }^{2}$, Kehan Bao $^{1}$, Jessica Piesz ${ }^{1}$, Anu Frank-Lawale ${ }^{3}$, Ximing Guo ${ }^{4}$, Paul Rawson $^{5}$, Standish K. Allen Jr. ${ }^{3}$

${ }^{1}$ Department of Fisheries, Animal and Veterinary Science, 170 CBLS, 120 Flagg Road, Kingston, RI, 02881, USA

${ }^{2}$ Agricultural Research Services, NCWMAC, 469 CBLS, 120 Flagg Road, Kingston, RI, 02881, USA

${ }^{3}$ Virginia Institute of Marine Sciences, College of William \& Mary, Rt. 1208 Greate Road, Gloucester Point, VA, 23062, USA

${ }^{4}$ Rutgers University, 6959 Miller Ave, Port Norris, NJ, 08349, USA

${ }^{5}$ University of Maine, 5751 Murray Hall, Orono, ME, 04469, USA

Populations of the eastern oyster, Crassostrea virginica have been severely affected in the last few decades by diseases such as Dermo, MSX, SSO, and ROD. In order to manage these diseases, there is a need for effective breeding programs that produce specific genetic lines that perform optimally in very diverse shellfish-growing environments. Six selectively-bred lines of $C$. virginica were deployed in five sites along the east coast of the US, from Virginia to Maine, in August 2012. Growth and survival were measured for 16 months and samples were collected in cases of high-mortality events for disease diagnosis and future genotyping. Line performance (yield) was mainly driven by survival. Strong genotype by environment interactions were observed: three of the northern lines (UMaine, NEH-RI, and Clinton) were significantly larger and had significantly higher survival rates than the southern lines (hANA and DEBY) in the Rhode Island sites, while the southern lines had a higher yield than the northern lines in the Delaware and Chesapeake Bay sites. Dermo and MSX were the most-likely causes of high mortality among the northern lines in the Delaware and Chesapeake Bay sites, while ROD caused large mortalities in oysters deployed in Maine. More research needs to be done to identify what other diseases or environmental factors drove the site-specific performance of these lines at northern sites. These results suggest local adaptation of selectively-bred oyster lines to the site of origin and a need for the development of regional breeding programs.

\section{DEMONSTRATION OF LIVING SHORELINE TECHNOLOGY ON MARTHA'S VINEYARD, MA \\ Emma Green-Beach, Richard Karney, Amandine Surier, Chris Edwards \\ Martha's Vineyard Shellfish Group Inc., PO Box 1552, Oak Bluffs, MA, 02557, USA}

On Martha's Vineyard there is little salt marsh compared to more southern locations. Marshes on Martha's Vineyard are not threatened by storm erosion or boat wake to the same degree as other locales, yet there is great ecological value in the small amount that exists. Nutrient cycling and attenuation is one of the most critical services provided by marshes and nitrogen eutrophication is perhaps the greatest threat to the health of salt ponds and embayments on Martha's Vineyard. This project was designed with the goals of demonstrating "Living Shoreline" techniques in embayments on Martha's Vineyard that can be used elsewhere in our region, and also to conduct preliminary investigations into the hatchery production of the ribbed mussel Geukensia demissa. Four sites were selected for installation of coir logs, marsh grass, and ribbed mussels for pilot-scale marsh restoration. Two of the four sites are in Lagoon Pond and two are in Sengekontacket Pond; one site in each coastal pond experiences low wave-energy, while the other is in a more high energy location. The rational for this design is to be able to evaluate the application of the technology at different types of sites. To date, living shorelines have been installed in both low-energy sites.

\section{DERIVED MACROALGAE FEED AND ITS POTENTIAL USE IN SHELLFISH AQUACULTURE \\ Zach Hope}

University of New England, 11 Hills Beach Road, Biddeford, ME, 04005, USA

The green macroalgae Ulva is a globally distributed seaweed with fast growth rates and relatively high nutritional value. In recent years, massive accumulations of "green tides" of Ulva have occurred with increased frequency and magnitude resulting in deleterious effects to coastal ecosystems. If left in coastal waters, decomposing biomass results in oxygen-depleted waters inhospitable to other organisms. If harvested, the biomass is often incinerated or buried due lack of commercial use and value. The present study will investigate the potential use of Ulva in hatchery diets for shellfish. Ulva will be analyzed for its chemical composition and compared to traditional feeds used in aquaculture. Ulva will be broken down to a size fractionation suitable for shellfish ingestion both mechanically and with bacteria. Bacterial degradation is beneficial in breaking down the seaweed as well as increasing protein content. A suitable use for Ulva in aquaculture would help alleviate problems caused by "green tides" as well as supply shellfish hatcheries a sustainable supplement or replacement for currently, more costly feeding regimens. 
THE APPLICATION OF A QUANTITATIVE PCR WITH A PLASMID STANDARD CURVE TO EVALUATE PERKINSUS MARINUS LEVELS IN THE EASTERN OYSTER, CRASSOSTREA VIRGINICA

Whitney Jaillet, Kathryn Markey, Roxanna Smolowitz

Roger Williams University, 1 Old Ferry Rd., Bristol, RI, 02809, USA

Dermo Disease, caused by the endoparasite Perkinsus marinus, is responsible for significant morbidity and mortality in populations of Crassostrea virginica along the Atlantic coast of the United States. Currently, the gold standard for detection of Dermo disease is the Ray's Fluid Thioglycollate Medium (RFTM) assay. The RFTM method reports animal infection intensities using the Mackin scale, where 0 indicates no infection and 5 indicates heavy infection. In order to improve upon several shortfalls of RFTM, several molecular assays have been developed to increase specificity, accuracy, and speed of results. Recently, the Aquatic Diagnostic Laboratory (ADL) at Roger Williams University has developed a quantitative PCR (qPCR) that has been adapted from previous qPCR assays to employ a plasmid standard curve in lieu of a standard curve based on dilutions of cell cultures. The use of plasmid DNA allows us to generate a consistently linear and highly reproducible standard curve for the assay without the need to culture and extract $P$. marinus cells regularly. This new assay has been equated to the traditional Mackin scale by extracting tissues of oysters $(n=86)$ with known Mackin ratings, running them in the qPCR, and comparing the results to the original Mackin ratings. Subsequent results of our qPCR can be translated into the Mackin scale for direct comparison to historical data. This new diagnostic test is currently being used by the ADL for restoration disease surveys in Rhode Island as well as health checks for local aquaculturists.

LONG-TERM TRENDS OF PATHOGENIC VIBRIO SPP. POPULATIONS IN NEW HAMPSHIRE OYSTERS

Stephen H. Jones ${ }^{1,2}$, Erin Urquhart ${ }^{1,2}$, Meghan Hartwick ${ }^{1,3}$, Michael Taylor ${ }^{1,3}$, Vaughn S. Cooper ${ }^{1,3}$, Cheryl A. Whistler ${ }^{1,3}$

${ }^{1}$ Northeast Center for Vibrio Disease and Ecology, University of New Hampshire, Durham, NH, 03824, USA

${ }^{2}$ Department of Nature Resources and the Environment, University of New Hampshire, Durham, NH, 03824, USA

${ }^{3}$ Department of Molecular, Cellular and Biomedical Sciences, University of New Hampshire, Durham, NH, 03824, USA

The incidence of confirmed vibriosis in the Northeast US has increased over the past decade. Whereas these include some cases not associated with shellfish consumption, the more recent trend of increasing incidence of regional shellfishborne Vibrio parahaemolyticus outbreaks has resulted in closed harvesting in some areas as well as product recalls. A long-term (2007-2014) Vibrio surveillance program in the Great Bay estuary of New Hampshire has tracked $V$. parahaemolyticus, Vibrio vulnificus and Vibrio cholerae in oysters, sediments, plankton and overlying water. The goals of this program include tracking the potential emergence of pathogenic sub-populations of these species, providing strains for in-depth determination of lineage and evolution, and determining environmental conditions that explain Vibrio population dynamics. Here we summarize our progress with empirical modeling of $V$. parahaemolyticus populations and with pre- and post-harvest strategies to reduce Vibrio levels to minimize public health risks. These results provide a framework for understanding the recent emergence of Vibrios as a significant issue for shellfish aquaculture in the Northeast US.

\section{SHELLFISH SANITATION MANAGEMENT FRAMEWORK FOR AQUACULTURE SCALLOPS}

Kohl Kanwit, Alison Sirois, Meggan Dwyer

Maine Department of Marine Resources McKown Point, PO

Box 8, West Boothbay Harbor, ME, 04575, USA

The Maine Department of Marine Resources has worked with the sea scallop (Placopecten magellanicus) aquaculture industry over the past few years to develop a protocol for biotoxin monitoring and testing. In 2014, the first whole scallops were harvested and sold from Maine aquaculture sites. Unlike scallop adductor muscles, whole or roe-on scallops are included in the National Shellfish Sanitation Program (NSSP) and are therefore subject to the NSSP Model Ordinance. This includes compliance with harvester and dealer tagging, harvesting from growing areas with appropriate water quality standards, and biotoxin testing. Sea scallops are known to retain naturally occurring marine biotoxins longer than some other species of shellfish (e.g. blue mussel), so testing whole or roe on scallops for Paralytic Shellfish Poisoning (PSP) is of particular concern. Establishing a regulatory framework for sea scallop aquaculture with regard to shellfish sanitation will ensure the growth, profitability and safety of an emerging product from Maine waters. 
HUMAN HEALTH SAFETY CONSIDERATIONS FOR USING VIBRIO SP. PROBIOTIC STRAIN OY15 AS A FEED SUPPLEMENT TO IMPROVE SURVIVAL OF LARVAE OF THE EASTERN OYSTER (CRASSOSTREA VIRGINICA): GENOME SEQUENCING AND MAMMALIAN CYTOTOXICITY ASSAY

Diane Kapareiko ${ }^{1}$, Harold J. Schreier ${ }^{2}$, Eric J. Schott ${ }^{3}$, Dorothy Jeffress $^{1}$, Gary H. Wikfors ${ }^{1}$

${ }^{1}$ NOAA/NMFS, Northeast Fisheries Science Center, Milford Laboratory, 212 Rogers Avenue, Milford, CT, 06460, USA

${ }^{2}$ Department of Marine Biotechnology, Institute of Marine and Environmental Technology, University of Maryland Baltimore County, 701 E. Pratt St., Baltimore, MD, 21202, USA

${ }^{3}$ University of Maryland Center for Environmental Science, Institute of Marine and Environmental Technology, 701 E. Pratt St., Baltimore, MD, 21202, USA

Use of beneficial bacterial probiotics for controlling microbial pathogens in aquaculture is an environmentally-friendly alternative management practice for disease prevention. The Milford Laboratory has isolated and evaluated a naturally-occurring Vibrio sp. probiotic isolate (OY15) from the digestive glands of adult eastern oysters (Crassostrea virginica) that has been confirmed safe for use with oyster larvae and their microalgal feed T-ISO, and can improve survival of larvae challenged with a shellfish pathogen by $20-35 \%$. Sequence analysis of OY15 revealed closest matches to Vibrio sp. EX25 and Vibrio alginolyticus. This study discusses a three-part human health safety assessment to determine probiotic strain OY15's safety during applications in commercial larviculture. First, antibiotic sensitivity testing against 14 antibiotics used for humans confirmed OY15's sensitivity to 12 of these antibiotics. Next, annotation of a draft genome sequence for probiotic OY15 indicated the genetic capacity to produce a variety of potentially probiotic proteins. Several Rhs family genes were present that stimulate host immunity and may be partially responsible for OY 15 's probiotic effects. Genes for quorum sensing regulators and siderophores important for colonization of the digestive tract were found, as well as an accessory colonization factor (AcfA). A number of virulence-related hemolysins, regulators and secretion system components were found. However, $t d h$ and $t r h$ genes associated with virulent $V$. parahaemolyticus were absent. Lastly, a mammaliancell culture bioassay used to test OY15 for cytotoxicity confirmed no cytotoxic effects on the human cell line Caco-2 by OY15. Taken together, these data suggest a low human virulence risk for probiotic strain OY15.

\section{GETTING THE N OUT - A SEARCH FOR BIOREMEDIATION ALTERNATIVES TO SEWAGE TREATMENT Richard Karney $^{1}$, Emma Green-Beach ${ }^{1}$, Paul Carey ${ }^{2}$ \\ ${ }^{1}$ Martha's Vineyard Shellfish Group, Inc., PO Box 1552, Oak Bluffs, MA, 02557, USA \\ ${ }^{2}$ Wastewater Alternatives, 362 Coburn Avenue, Worcester, MA, 01604, USA}

In recent years, studies by the Massachusetts Estuaries Program (MEP) have confirmed that high nitrogen loading, especially from onsite septic systems, is the primary driver of the degraded environmental quality observed in many of the state's estuaries. The MEP studies have developed target Total Maximum Daily Loads (TMDLs) for nitrogen required to reverse eutrophic conditions and restore water quality. Local municipalities have been tasked with developing plans to meet the target nitrogen reductions. Conventional tertiary sewage treatment systems are the likely means to that end. However, because of the high costs for construction and operation of these systems, municipalities are seeking more affordable alternatives. Further, because much of the problematic nitrogen enters the embayments though slow moving groundwater plumes, the damaging impacts of nitrogen will continue for years after the installation of treatment systems. The Martha's Vineyard Shellfish Group is investigating a number of potential methodologies to enhance bioremediation of nitrogen within our local estuaries. Within the environmental, social and regulatory conditions that exist at various sites, we are exploring the feasibility of using oysters, ribbed mussels Geukensia demissa, Phragmites australis, Floating Islands and living shorelines to reduce nitrogen levels in the impaired estuaries.

\section{PREDATION ON JUVENILE SOFT SHELL CLAMS: THE SCOURGE OF THE GREEN CRABS}

Amanda Keegan, Mark Fregeau

NEMAC Cat Cove, Salem State University, Salem, MA, 01970, USA

Shellfish farmers suffer a significant loss of their crop each year due to a variety of predators, specifically green crabs (Carcinus maenas). Trapping studies show that green crabs can occur in high densities in clam flats, which can result in high mortalities of juvenile clams. Although baited traps provide some general information on crab population dynamics, there are few quantitative studies to examine actual crab densities in naturally occurring clam flats. This study was designed to quantitatively observe the green crab impacts on juvenile soft shell clams (Mya arenaria) in situ utilizing multiple mudflat plots. Experimental design included four treatments consisting: seeded covered by a net, seeded without net, no seeding with net, and no seeding without net (control). Weekly monitoring recorded clam densities and size of resident, planted, and newly recruited clams; along 
with the presence and size of green crabs. The data shows that small, newly recruited green crabs have minimal impact on juvenile soft shell clams. These smaller, newly settled green crabs may be too small to effectively prey on juvenile clams. While larger green crabs can consume netted clams, the use of nets to exclude these crabs in addition to regular net monitoring to remove newly settled green crabs may drastically reduce the impact of crab predation and enhance clam survival. This study will continue through the winter to explore possible seasonal trends in clam-crab interactions.

IN VIVO FLUORESCENCE BASED CHLOROPHYLL A MEASUREMENTS - HOW CLOSE ARE WE TO THE TRUTH?

Judy Yaqin Li, Mark Dixon, Shannon Meseck, Barry Smith, Julie Rose, Gary Wikfors

NOAA/NMFS, Northeast Fisheries Science Center, Milford Laboratory, 212 Rogers Avenue, Milford, CT, 06460, USA

Food availability is one of the most important factors in bivalve shellfish aquaculture site selection, whether the goal is food production or ecosystem restoration purposes. Although bivalve shellfish consume bacteria, detritus, and small-sized zooplankton, phytoplankton is typically the most abundant food group available. Ways to measure the availability of food include cell abundance, chlorophyll $a$ concentration and dry weight of particular organic matter in the water. These methods all involve collecting discrete water samples and processing samples in the lab. Alternatively, in vivo fluorescence based chlorophyll $a$ estimate allows unattended continuous data collection. The high efficiency fluorescence method makes excellent temporal coverage possible, which is important given large temporal variability in phytoplankton abundance in the estuarine environment. There are, however, inherent problems associated with converting the fluorescence signal into chlorophyll $a$ concentration. The taxonomical composition of phytoplankton assemblage and the physiological status of the community all affect the in vivo fluorescence. Moreover, the non-photochemical quenching of fluorescence at high irradiance causes the underestimation of chlorophyll a concentration during the day. Long-term time series of in vivo fluorescence data collected from Riverhead, Long Island, New York and Milford Harbor, Connecticut using a YSI sensor were corrected for non-photochemical quenching. Data collected from the East River tidal strait, New York did not seem to be greatly influenced by the non-photochemical quenching. The turbid condition at the East River tidal straight may be shielding phytoplankton community from high irradiance during the day.
VIABILITY OF PERKINSUS MARINUS IN SEAWATER Joseph Looney $^{1}$, Lauren Huey ${ }^{1}$, William Schroer ${ }^{1,2}$, Tal Ben-Horin ${ }^{1}$, Daphne Munroe ${ }^{1}$, David Bushek ${ }^{1}$

${ }^{1}$ Haskin Shellfish Research Laboratory, Rutgers University, 6959 Miller Ave, Port Norris, NJ, 08349, USA

${ }^{2}$ Allegheny College, 520 North Main St., Meadville, PA, 16335, USA

Understanding the inactivation kinetics of pathogenic microorganisms in seawater is essential for predicting the spread of infectious diseases through populations of fish and invertebrates. The protozoan Perkinsus marinus causes significant mortality in its ecologically and commercially important host, the eastern oyster Crassostrea virginica. As part of a broader effort to develop predictive models of disease transmission and spread in marine systems, we inoculated an environmental Perkinsus marinus isolate (ATCC ${ }^{\circledR}$ strain 50509, “DBNJ") into sterile filtered seawater microcosms at varying salinities (15, 20 and $25 \mathrm{ppt}$ ), and fitted daily cell viability data to competing models of pathogen survival. We found the survival of Perkinsus marinus to increase with salinity, a result that echoes patterns of this pathogen's virulence across estuary salinity gradients. Our results also suggest that the rate of pathogen inactivation increases with the amount of time cells are in seawater. These results provide new insights into the transmission of Perkinsus marinus and will be used to improve ongoing efforts modeling the transmission and spread of marine diseases.

\section{ESTABLISHING OFFSHORE MUSSEL FARMS IN FEDERAL WATERS}

Edward Maney Jr., Mark Fregeau

Northeastern Massachusetts Aquaculture Center (NEMAC), Cat Cove Marine Laboratory, Department of Biology, Salem State University, Salem, MA, 01970, USA

For the past 2 years we have been working through the permitting process to obtain an Army Corps of Engineers (ACOE) permit pursuant to Section 10 of the Rivers and Harbors Act of 1899 to establish a commercial scale (33 acre) offshore mussel farm 8.5 miles off the coast of Cape Ann Massachusetts (NAE-2012-1598 NEMAC Aquaculture). We plan to begin deployment of 1 to 3 longlines this spring as a pilot research study to explore best practices for offshore shellfish aquaculture as well as monitoring potential fishery and habitat enhancement effects attributed to shellfish aquaculture in offshore waters. This site is within the Northern Temporary Paralytic Shellfish Poison Closure Area (50 CFR Part 648). We will acquire a Letter of Authorization (LOA) to conduct research on controlled experimental harvests to provide samples to indicate the PSP toxin 
levels are below the regulatory limit necessary to allow commercial harvests. After this initial pilot research study, we plan to expand the number of longlines to a commercial scale farm with 32 to $400 \mathrm{ft}$ longlines. Our ultimate objective is to refine and enhance offshore mussel culture as an alternative fishing option for fishermen and lobstermen currently displaced or negatively impacted by current fishery restrictions by providing an incubator farm site for interested parties to try offshore aquaculture.

A PRELIMINARY ASSESSMENT OF THE EFFECT OF INCREASED SEAWATER ACIDITY ON JUVENILE BAY SCALLOPS (ARGOPECTEN IRRADIANS IRRADIANS) FROM TWO GENETIC LINES

Isaiah Mansour $^{1}$, Sheila Stiles ${ }^{2}$, Joseph Choromanski ${ }^{2}$

${ }^{1}$ University of Maine, 223 Ballentine Hall, Orono, ME, 04469, USA

${ }^{2}$ NOAA/NMFS, Northeast Fisheries Science Center, Milford Laboratory, 212 Rogers Avenue, Milford, CT, 06460, USA

Geographically isolated populations of the bay scallop (Argopecten irradians irradians), may exhibit differential resistance to developmental inhibition and mortality caused by ocean acidification. The determination of $\mathrm{pH}$-resilient genetic lines for wild stock supplemental aquaculture would aid ongoing population conservation efforts. For this purpose, juvenile scallops from the $\mathrm{F}_{2}$ generation of two genetic lines, one from Niantic, CT broodstock and the other from Nantucket, MA broodstock, were exposed to seawater of increased acidity with $\mathrm{CO}_{2}$ in a shortterm study. Three replicates each of $35 \mathrm{~F}_{2}$ Niantic scallops and three replicates each of $35 \mathrm{~F}_{2}$ Nantucket scallops were maintained in beakers of seawater with a $\mathrm{pH}$ of 7.9 as controls, for 6 days. Simultaneously, similar groups of juvenile bay scallops were maintained in seawater with a $\mathrm{pH}$ of 7.5 , as experimental groups. Tetraselmis was drip fed into the system. The effect of acidified seawater on the growth of the scallops was measured by individual shell length at the beginning and end of the study. Scallops from the CT broodstock grew larger in both control and acidified seawater than the scallops from the MA broodstock. There was negligible mortality in all groups. Thus genetic background might be a relevant factor, in addition to environmental parameters, in predicting juvenile scallop growth under various conditions. Should continued investigations yield similar results, a well-adapted genetic line could be developed for aquaculture and conservation.

\section{DEVELOPMENT AND APPLICATION OF A DUPLEX QPCR FOR THE DETECTION OF VIBRIO PARAHAEMOLYTICUS AND VIBRIO VULNIFICUS IN ENRICHED OYSTER HOMOGENATES FROM RHODE ISLAND AND MASSACHUSETTS \\ Kathryn R. Markey, Roxanna Smolowitz \\ Roger Williams University, 1 Old Ferry Rd., Bristol, RI, 02809, USA}

Increased summer water temperatures have heightened human health concerns for the shellfish aquaculture industry. Increased temperatures potentiate a proliferation in the growth of Vibrio parahaemolyticus $(\mathrm{Vp})$ and Vibrio vulnificus $(\mathrm{Vv})$ in cultured oysters. The Aquatic Diagnostic Laboratory (ADL) at Roger Williams University in Bristol, RI has been monitoring Vp and $\mathrm{Vv}$ levels in two local oyster farms (one in RI and one in MA) during the summer of 2014. Samples from these sites were processed using traditional 3-tube MPN along with MPN-qPCR. The qPCR technique used is a duplex assay for both $\mathrm{Vp}$ and $\mathrm{Vv}$, using the general $t h$ gene for $\mathrm{Vp}$ and the tox $R$ gene for $\mathrm{Vv}$. The assay was developed in 2013 in the ADL and continues to be an accurate and reliable method. Post-enrichment MPN samples were cultured using TCBS and Vibrio CHROM agar to verify the presence of the $\mathrm{Vv}$ and $\mathrm{Vp}$. An efficient and reliable DNA extraction method has been determined for post-enrichment MPN samples. The method focuses on comparing qPCR data from a subsample of the $10 \mathrm{~g}$ sample of enriched oyster homogenate with the 3-tube MPN using the duplex qPCR.

\section{PREVALENCE, INTENSITY AND MOLECULAR DETECTION OF THE TREMATODE PROCTOECES MACULATUS IN MYTILUS EDULIS}

Kelly N. Markowitz, Maureen K. Krause, Jason D. Williams

Department of Biology, Hofstra University, Hempstead, NY, 11549, USA

The digenetic trematode Proctoeces maculatus (Looss, 1901) is a pervasive parasite of numerous mollusc and fish species. Infections of sporocyst stage Proctoeces maculatus are predominately found in the mantle tissue of molluscan hosts such as Mytilus edulis. Although it is not well studied, it has been suggested that infection by this trematode may contribute to mussel mortality. The purpose of this study was to assess the prevalence and intensity of $P$. maculatus parasitism in mussels from several sites along coastal Long Island, NY, and from a few sites further north along the New England coast. Finally, we wanted to develop a speciesspecific molecular assay to detect these trematode parasites in mussel tissue. We sequenced a region of the $18 \mathrm{~S}$ rDNA and used this to develop a molecular assay for detection of $P$. maculatus. Overall our results from microscopic and molecular detection of the parasite suggest that trematode intensity is much greater than previously reported. Parasitization of the mantle tissue may reach 
350 sporocysts $/ 100 \mathrm{~mm}^{2}$ in some mussel populations. Even when there is no evidence of either live sporocysts or cercaria, remnant sporocysts are often found in mussels. Climate change may be contributing to a northern range expansion for this parasite, as they are found in mussel populations from New England, with potential impacts on mussel aquaculture.

\section{SCREENING BIOFOULING ORGANISMS AROUND OYSTER CAGES FOR POTENTIAL RESERVOIR SPECIES OR INTERMEDIATE HOSTS OF THE OYSTER PARASITE MSX IN THE DAMARISCOTTA ESTUARY}

Nicole Messerman, Timothy Bowden

Aquaculture Research Institute, School of Food \& Agriculture, 5735 Hitchner Hall, University of Maine, Orono, ME, 04469-5735, USA

In 2010 the oyster parasite MSX was reported in the Damariscotta Estuary resulting in significant mortalities. Whilst there are many studies on this parasite very little is known about its life cycle as it has proved impossible to transfer the infection to naive oysters. This has always indicated that an intermediate host is necessary. In an effort to identify potential reservoir species or even an intermediate host, we screened local biofouling organisms and plankton samples for the presence of the parasite. Using PCR techniques we found no obvious candidates for either reservoir species or intermediate host, although the parasite did seem to be present at low levels in some of the samples.

\section{COPING WITH COPIOUS FRESHWATER IN MIDCOAST Bill Mook}

Mook Sea Farms, 321 State Route 129, Walpole, ME, 04573, USA

While the global ocean acidification process is inexorably occurring, in nearshore coastal areas other acidifying forces can eclipse it. The most publicized example of this occurs on the West Coast, where wind driven upwelling of acidic waters caused the near collapse of the oyster industry in Washington. Another nearshore effect of increasing atmospheric greenhouse gases may account for observations of oyster larvae performance made at Mook Sea Farm (MSF), on the Damariscotta River in Midcoast Maine. Over the last 50 years the northeastern U.S. has experienced an increase in both annual precipitation and the frequency of large precipitation events. At MSF, reductions in larval feeding and growth were observed to occur in conjunction with storms resulting in large amounts of freshwater runoff. Over the course of several years a suite of changes in larval culture techniques have been tested and made part of MSF's standard protocol. All of these changes are aimed at improving carbonate chemistry parameters experienced by the larvae, and in the 2014 production season they were applied consistently to all spawns. In sharp contrast to other years, every larval cohort reached setting size in 14-16 days, and conversion rates from larvae to post-set averaged over $60 \%$. Starting in April 2014, monitoring equipment was installed on MSF's intake line to continuously measure (and calculate) key carbonate parameters. The results suggest that natural populations are experiencing suboptimal conditions as determined by recent studies. This raises questions about genetic adaptation and recruitment success of natural shellfish populations.

PROGRESS IN AQUACULTURE OF SEA SCALLOPS (PLACOPECTEN MAGELLANICUS) IN MAINE

Dana Morse ${ }^{1}$, Togue Brawn ${ }^{2}$, Marsden Brewer ${ }^{3}$, Terry Gray ${ }^{4}$, Mark Green ${ }^{5}$, Kohl Kanwit ${ }^{6}$, Nate Perry ${ }^{7}$, Kevin Scott $^{8}$, Peter Stocks $^{9}$, Evan Young ${ }^{10}$

${ }^{1}$ Maine Sea Grant/University of Maine Cooperative Extension, Darling Marine Center, 193 Clark's Cove Road, Walpole, ME, 04573, USA

${ }^{2}$ Maine Dayboat Scallops, 39 Asselyn Drive, Scarborough, ME, 04074, USA

${ }^{3} \mathrm{~F} / \mathrm{V}$ Lindsay Marie, 88 North Stonington Road, Stonington, ME, 04681, USA

${ }^{4} 110$ West Side Drive, Verona Island, ME, 04416, USA

${ }^{5}$ Peaks Island Shellfish, 5 Willow Street Peaks Island, ME, 04108, USA

${ }^{6}$ Maine Department of Marine Resources, PO Box 8, W. Boothbay Harbor, ME, 04575, USA

${ }^{7}$ Pine Point Oyster Co., 10 Pine Ridge Road, Cape Elizabeth, ME, 04107, USA

${ }^{8} 37$ Cross Road, Hancock, ME, 04640, USA

${ }^{9}$ Trundy Point, LLC, 98 Colchester Drive, South Portland, ME, 04106, USA

${ }^{10} \mathrm{E}+\mathrm{K}$ Shellfish, 346 Old Route 1, Hancock, ME, 04640, USA

Progress in the production of sea scallops (Placopecten magellanicus) in Maine has been rapid in the years 2011-2014, spurred by a combination of changes in the regulatory environment and support at the state level, and through collaborations between shellfish growers, commercial fishermen and extension professionals. The results to date have shown that sea scallops can be sourced, grown and sold successfully and safely, and initial returns indicate that scallop production can be a profitable enterprise. Significant contributions to local knowledge have also come through conversations with scallop producers in Atlantic Canada and Japan. Presently, scallops are in production on seven Maine shellfish farms, and recent grant support will advance understanding of market conditions and preferences. Importantly, by virtue of the scallops' ability to absorb and retain high levels of biotoxins, the sale of live/whole/roe-on scallops represents a unique risk, and the importance of proper product testing and knowledgeable producers cannot be overstated. 
UPWELLING OF ACIDIFIED WATER: NOT JUST AN ISSUE FOR SHELLFISH HATCHERIES ON THE WEST COAST OF THE US

Daphne Munroe', Matthew Poach ${ }^{2}$, Ian Abrahamsen ${ }^{3}$, Sarah Borsetti $^{1}$

${ }^{1}$ Rutgers University, Haskin Shellfish Research Laboratory, Port Norris, NJ, 08349, USA

${ }^{2}$ NOAA/NMFS, Northeast Fisheries Science Center, James J. Howard Marine Sciences Laboratory, Highlands, NJ, 07732, USA

${ }^{3}$ University of Pittsburgh, Pittsburgh, PA, 15260, USA

Periodic summer upwelling events are known to occur off the coast of New Jersey. As with upwelling off the US West Coast, these events can transport deep, acidified water to the surface and shoreward. To determine if upwelling events have the potential to impact shellfish hatcheries in New Jersey, a monitoring study was conducted at the Aquaculture Innovation Center (AIC) of Rutgers University. The AIC is an important research hatchery that currently supports the New Jersey oyster aquaculture industry through the production of disease resistant and triploid seed oysters. Starting in June of 2014, temperature, salinity, dissolved oxygen, turbidity and $\mathrm{pH}$ were continuously monitored at the AIC's intake pipe located in the Cape May Canal. Periodic duplicate grab samples were also collected at the intake and at locations within the facility. One of each duplicate grab samples was preserved and analyzed for $\mathrm{pH}$ and dissolved inorganic carbon (DIC), whilst the other was preserved for analysis of the planktonic community. DIC and $\mathrm{pH}$ were used to calculate the aragonite saturation state of the sampled water. During an upwelling event in early July, a decrease in $\mathrm{pH}$ was measured at the intake. Likewise, grab samples showed that water of low $\mathrm{pH}$ and aragonite saturation was entering the facility. These results show that hatcheries along the NJ coast need to be aware that upwelling may bring reduced shellfish production conditions, and highlights the need for continued monitoring.

ARE THE AQUACULTURE PRACTICES SUSTAINING OUR GOAL TO RESTORE OYSTERS (CRASSOSTREA VIRGINICA)?

Gulnihal Ozbay, Brian Reckenbeil, Frank Marenghi, Patrick Erbland

Delaware State University, Department of Agriculture and Natural Resources, Dover, DE, 19901, USA

Decline of eastern oyster stocks along the east coast of the United States, particularly in the Mid-Atlantic area, have prompted the implementation of many types of restoration efforts. Delaware's oyster gardening program cooperates with volunteer growers in the three coastal bays of the Delaware Inland Bays. Research efforts in the DIB have focused on monitoring oyster growth and survival, water quality conditions, species diversity and abundance in and around oyster aquaculture and riprap habitats. Riprap is designated as the final destination of oysters cultured by the volunteer oyster gardeners. Our research effort provides baseline information on the ecological value of oyster aquaculture in Delaware's Inland Bays. We found newly settled juvenile oysters for the first time within floating oyster gear in man-made, residential canal systems, and on riprap shorelines around the DIB. Many species of economic and ecological importance are considered habitat-limited in the Inland Bays, particularly regarding juvenile refugia and forage areas. Oyster aquaculture gear can provide habitat for these native estuarine fauna at small scales, while supplementing oyster spawning stocks and enhancing natural recruitment, without difficult and costly types of habitat modifications. Although aquaculture sites or gear are clearly not structurally or functionally equivalent to natural reefs, research conducted over eight years in Delaware Inland Bays revealed the diversity of species found in and around oyster culture sites to be quite encouraging. As enhancement and restoration efforts of oysters move forward, it is important to understand the impacts of oyster aquaculture on the surrounding habitat and biological community.

PRODUCTION OF THE FIRE SHRIMP (LYSMATA DEBELIUS) USING A CLOSED-LOOP RECIRCULATING LARVAL REARING SYSTEM

Alisha Patel ${ }^{1}$, Melanie Fuoco ${ }^{1}$, Bradford Bourque ${ }^{1}$, Joseph Szczebak $^{1}$, Andrew Rhyne ${ }^{1,2}$

${ }^{1}$ Center for Economic and Environmental Development, Roger Williams University, One Old Ferry Road, Bristol, RI, 02809, USA

${ }^{2}$ John H. Prescott Marine Laboratory, The New England Aquarium, Central Wharf, Boston, MA, 02110, USA

The fire shrimp, Lysmata debelius, is one of the top marine invertebrates sold in the aquarium trade. Wild capture of fire shrimp from Sri Lanka is the primary source to the aquarium trade and aquaculture of this species would help prevent over-exploitation of wild populations. To date, large-scale aquaculture of fire shrimp has been bottlenecked by the long planktonic larval stage in combination with strong juvenile aggression. A closed recirculating larval rearing system was developed to optimize the production of this species. The design and operation of this rearing system have increased production efficiency to a potentially commercial-scale level. Larvae are hatched directly into the larval system and are evenly distributed throughout the rearing tanks. The shape and water flow dynamics of the larval rearing tanks suspends shrimp within the water column without damaging their delicate appendages, which greatly affects survival and growth. Fire shrimp larvae are fed N1-stage Artemia for the duration of the larval period. The system is equipped with changeable overflow screens, which allow retention of N1 Artemia for feeding and removal of N2+ Artemia 
before the next feed. Post-metamorphosis shrimp are weaned onto a pellet diet. Survival rates have exceeded $75 \%$ using this system while previous production techniques averaged below $10 \%$. The time to metamorphosis has also improved from over 160 days to less than 60 days, and over 800 of juveniles have been produced from a single hatch using these methods.

\section{ACIDIC MUD AND CLAM SHELL PITTING IN CASCO} BAY, MAINE

Joe Payne

Friends of Casco Bay/Casco Baykeeper, 43 Slocum Drive, South Portland, ME, 04106, USA

Soft shell clam (Mya arenaria) harvesting is the third largest fishery in Maine and important to the coastal economy. Research has shown that clam spat can dissolve in low $\mathrm{pH}$ (acidic) mud. It is also known that clam spat can reject settling on mud if the conditions are unfavorable, including low $\mathrm{pH}$. In order to determine if there were flats in Casco Bay with acidic mud, we did a survey checking $\mathrm{pH}$ at the tidal midpoint on 30 clam flats. Results showed that most of the flats had $\mathrm{pH}$ levels significantly below the ambient water $\mathrm{pH}$. Some mud had $\mathrm{pH}$ levels at or lower than laboratory values that caused complete dissolution of clam spat. Next, we sampled one flat more intensively checking $\mathrm{pH}$ at five stations on a transect from high tide to low tide. We did this twice a month from June through September. The $\mathrm{pH}$ varied with seasonal temperatures but the relative trend was stable through all months: the $\mathrm{pH}$ continually decreased from the high tide zone toward the low water mark. Mud samples were also taken and the pore water analyzed for dissolved inorganic carbon and total alkalinity; then $\mathrm{pH}$ and $\Omega_{\text {aragonite }}$ were calculated. There was strong correlation between the field $\mathrm{pH}$ and the calculated $\mathrm{pH}$, and between the field $\mathrm{pH}$ and $\Omega_{\text {aragonite. Lastly, hatchery clam spat }}$ were set out at the same flat then recovered after one week. Heavy pitting was observed. Natural spat were collected at the same location and pitting was also observed.

\section{THE EFFECTS OF TEMPERATURE AND PHOTOPERIOD ON BLUE MUSSEL (MYTILUS EDULIS) HEALTH} Kyle Pfau ${ }^{1}$, Brian M. Preziosi², Timothy Bowden ${ }^{2}$

${ }^{1}$ University of Maine, School of Marine Sciences, 5706 Aubert Hall, Orono, ME, 04469, USA

${ }^{2}$ University of Maine, School of Food and Agriculture, 5735 Hitchner Hall, Orono, ME, 04469, USA

The blue mussel, Mytilus edulis, is an important aquaculture species in Maine. To help growers better understand the combined effects of photoperiods and temperature on M. edulis we maintained this species at the University of Maine's Aquaculture Research Center in 2 different photoperiods ( $16 \mathrm{~h}$ light $/ 8 \mathrm{~h}$ dark and $16 \mathrm{~h}$ dark $/ 8 \mathrm{~h}$ dark) and temperatures $\left(5^{\circ} \mathrm{C}\right.$ and $\left.15^{\circ} \mathrm{C}\right)$ for 3 months. A treatment group was created for each temperature and photoperiod combination, each containing 2 tanks. Mussels were sampled 3 times during the duration of the experiments $(n=14$ per treatment) with 6 weeks between each sample point. We measured lysozyme content in the serum, superoxide dismustase (SOD) content in the gills, flesh to shell weight ratios, and mortality. For serum lysozyme levels, no significant differences were found between any of the treatments. SOD values were immensely elevated at the second sample point for both the $15^{\circ} \mathrm{C}$ treatments and then, at the third sample point, we observed a decrease down to values that were still at least twice the values found at the first sample point. SOD values for $5^{\circ} \mathrm{C}$ treatments varied by photoperiod treatment with the $16 \mathrm{~h}$ light cycle showing no difference and the $8 \mathrm{~h}$ light cycle showing a gradual increase as the experiment progressed. Flesh to shell weight ratios decreased as the experiment progressed much faster in $15^{\circ} \mathrm{C}$ groups than it in $5^{\circ} \mathrm{C}$ groups. Mortality was much higher in the $15^{\circ} \mathrm{C}$ tanks than the $5^{\circ} \mathrm{C}$ tanks.

\section{THE EUROPEAN GREEN CRAB - FINDING ALTERNATIVE USES FOR AN INVASIVE PREDATOR IN PRINCE EDWARD ISLAND}

Luke Poirier $^{1}$, Sophie St-Hilaire ${ }^{2}$, Jeff Davidson ${ }^{2}$, Jonathan Hill ${ }^{2}$, Pedro Quijon'

${ }^{1}$ University of Prince Edward Island, Department of Biology, 550 University Avenue, Charlottetown, PEI, Canada, C1A4P3

${ }^{2}$ Atlantic Veterinary College, Department of Health Management, 550 University Avenue, Charlottetown, PEI, Canada, C1A4P3

Over the past decade and a half, the growth of green crab (Carcinus maenas) populations has become a concern to the sustainability of shellfish resources and healthy aquatic systems in Atlantic Canada. With most attempts at eradication in this and other regions proving unsuccessful, there is a distinct need for novel mitigation measures. Recently, the Department of Fisheries and Oceans (DFO) Canada established a fishery for green crab in Atlantic Canada, but the long-term viability of this fledgling fishery is questionable without the identification of suitable marketable products. The development of a "soft-shell" product is an attractive option that could mimic the successful soft-shell Blue crab industry in the USA and the soft-shell Mediterranean crab (moleche) industry in Venice, Italy. In order to assess its feasibility, a pilot project was initiated in PEI in spring 2014. Crabs were collected using both passive and active trapping methods and external physical characteristics were carefully identified and recorded based on traditional knowledge acquired from Venetian moleche fishers. Crabs were then held in individual compartments for 2 to 3 weeks and molting occurrence was observed. Initial results suggest synchronized "molting windows" during the spring (males) and autumn (females). Based on preliminary molting rates, a second phase of this study intends to work in co-operation with local shellfish processors to assess the feasibility of an economically viable and ecologically sustainable strategy based on molting recognition or induction in Green crabs. 
CLASSIFICATION OF ATLANTIC RAZOR CLAM (ENSIS DIRECTUS) HEMOCYTES USING LIGHT AND TRANSMISSION ELECTRON MICROSCOPY

Brian M. Preziosi, Timothy Bowden

University of Maine, School of Food and Agriculture, 5735

Hitchner Hall, Orono, ME, 04469, USA

The Atlantic razor clam, Ensis directus, is currently being researched as a potential species for aquaculture operations in Maine. To help lay the foundation needed for future health studies in this species, we looked at the morphology of their circulating hemocytes using light and transmission electron microscopy (TEM). The 2 main types of hemocytes found were granulocytes (granulated cells) and hyalinocytes (agranular cells). The granulocytes were subdivided into eosinophils and basophils due to the respective pink and purple shades their cytoplasm turned when stained with Hemacolor. Hyalinocytes were subdivided into large hyalinocytes and small hyalinocytes (blast-like cells) based on their nucleus to cytoplasm ratios. The large hyalinocytes had a small nucleus to cytoplasm ratio while the small hyalinocytes had a very large nucleus to cytoplasm ratio. In TEM micrographs, granulocytes observed were filled with many small granules and vacuoles while large hyalinocytes had cytoplasm comprised of mostly empty space. Small hyalinocytes had very little cytoplasm and contained only a few mitochondria. Differential hemocyte counts showed that granulocytes are present in much greater numbers than hyalinocytes in this species. We found that $E$. directus contains all cell types previously described in the literature for the related razor clam species Ensis siliqua with the addition of the large hyalinocyte cell type.

\section{ASSESSING THE EXTENT OF PHENOTYPIC VARIATION FOR DERMO RESISTANCE AMONG SELECTIVELY- BRED FAMILIES OF THE EASTERN OYSTER, CRASSOS- TREA VIRGINICA}

Dina A. Proestou ${ }^{1}$, Ryan J. Corbett ${ }^{2}$, Marta Gómez-Chiarri ${ }^{2}$, Jessica Moss Small ${ }^{3}$, Standish Allen, $\mathbf{J r}^{3}$

${ }^{1}$ USDA, Agricultural Research Service, NEA, NCWMAC, Shellfish Genetics Lab, 469 CBLS, 120 Flagg Road, Kingston, RI, 02881, USA

${ }^{2}$ Department of Fisheries, Animal and Veterinary Science, 170 CBLS, 120 Flagg Road, Kingston, RI, 02881, USA

${ }^{3}$ Virginia Institute of Marine Science, College of William \& Mary, Rt. 1208 Greate Road, Gloucester Point, VA, 23062, USA

Dermo disease impacts nearly every region where oysters are cultured in the Eastern U.S. and is a significant concern to industry stakeholders. Efforts to breed for Dermo resistance in the eastern oyster have had modest success, yet the range of existing phenotypic variation with respect to Dermo resistance among selectively bred families is not well characterized. The purpose of this study was to quantify the extent of phenotypic variation in the performance of $C$. virginica families upon exposure to the Dermo-causing parasite Perkinsus marinus under controlled conditions. Oysters $(\mathrm{N}=48)$ from each of 23 families were subdivided into challenged $(\mathrm{N}=24)$ and control $(\mathrm{N}=24)$ groups. Challenged oysters were notched and injected with $5 \times 10^{6}$ cultured Perkinsus cells per gram wet tissue weight while control oysters were injected with sterile salt solution. The two groups were maintained in separate flowing static systems at $25^{\circ} \mathrm{C}$ and $25 \mathrm{ppt}$ and mortalities were monitored each day for 42 days. Mantle, gill and digestive tissues were sampled from moribund oysters during the experiment as well as survivors at the end of the experiment to assess Perkinsus load. Mortality among challenged oysters varied by family and ranged from 42 to $100 \%$. The difference in mortality between challenged and control groups also spanned a wide range across families (4-54\%). These results suggest there is ample phenotypic variation in how oyster families respond to Dermo and will be coupled with parasite load data to identify which families best represent Dermo resistant oysters.

DISEASE-RESISTANCE AND IMPROVED PERFORMANCE FOR GENETICALLY IMPROVED AND CROSSBRED EASTERN OYSTERS, CRASSOSTREA VIRGINICA: RESULTS FROM A DECADE OF FIELD TRIALS IN NEW ENGLAND

Paul Rawson $^{1}$, Scott Lindell ${ }^{2}$, Ximing Guo ${ }^{3}$, Inke Sunila ${ }^{4}$

${ }^{1}$ School of Marine Sciences, University of Maine, Orono, ME, 04469, USA

${ }^{2}$ Program in Scientific Aquaculture, Marine Biological Laboratory, 7 MBL Street, Woods Hole, MA, 02543, USA

${ }^{3}$ Institute of Marine and Coastal Sciences, Rutgers, The State University of New Jersey, 6959 Miller Avenue, Port Norris, NJ, 08349, USA

${ }^{4}$ State of Connecticut, Department of Agriculture, Bureau of Aquaculture, P.O. Box 97, Milford, CT, 06460, USA

Substantial effort has been expended over the past five decades to develop genetically improved lines of eastern oysters (Crassostrea virginica) and has resulted in the production of several lines that demonstrate enhanced survival under specific disease pressures. In two field trials, we investigated the relative performance of the Rutgers University NEH, University of Maine UMFS, and Clinton lines, and interline hybrids when grown at sites across New England. Line performance in both trials was highly sitespecific; while there were significant differences in growth between sites, there was only subtle growth variation among lines. In 
contrast, line performance was heavily dependent on survival which was, in turn, dependent on disease pressure and linespecific disease resistance at each of our grow-out sites. Hybrid lines displayed very little, if any, improvement in growth relative to parental lines, and inherited varying degrees of disease resistance depending on the particular disease pressure experienced at a site. The differences in line performance are indicative of a high degree of genotype by environment interaction for survival and yield among the parental and hybrid lines. The prevalence of such interactions suggest that regional breeding programs should take advantage of the superior characteristics of the extant lines, but will need to consider alternatives to mass selection in order to build a breeding program that benefits growers and hatcheries throughout the region.

EXPERIMENTAL SYSTEM DESIGN FOR STUDYING THE EFFECTS OF ELEVATED LEVELS OF $\mathrm{CO}_{2}$ ON VARIOUS MARINE SPECIES

Dylan H. Redman ${ }^{1}$, Dean M. Perry ${ }^{1}$, George Sennefelder ${ }^{1}$, Christina McGraw ${ }^{2}$

${ }^{1}$ NOAA/NMFS, Northeast Fisheries Science Center, Milford Laboratory, 212 Rogers Avenue, Milford, CT, 06460, USA

${ }^{2}$ George Perkins Marsh Institute, Clark University, Worcester, MA, 01610, USA

At the NOAA laboratory in Milford, CT we have constructed a replicated flow-through seawater system capable of exposing an array of marine organisms to various levels of $\mathrm{pCO}_{2}$. The system uses water pumped into the lab from the Wepawaug River which is then sand-filtered and mixed with either heated or chilled seawater to achieve the desired water temperature. The system allows users to choose two treatment levels and a control which each feed three replicate 76 liter aquariums. Two 7' $(2.1 \mathrm{~m})$ sections of $4^{\prime \prime}(10.16 \mathrm{~cm})$ PVC pipe mounted vertically side by side make up the saturation chamber for each treatment. The level of $\mathrm{pCO}_{2}$ is achieved for each treatment by mixing the correct ratio of compressed air with research grade $\mathrm{CO}_{2}$ using mass flow controllers. The system can be setup to run in a flow-through mode which provides 1 liter per minute of seawater to each aquarium, or can be run statically. To date we have exposed blue crabs, Callinectes sapidus, black sea bass, Centropristis striata, scup, Stenotomus chrysops, and larval bay scallops, Argopecten irradians, to various levels of $\mathrm{pCO}_{2}$ in the system. For monitoring the $\mathrm{pH}$ levels we have constructed an automated sampling system that utilizes an Ocean Optics USB 2000+ ${ }^{\circledR}$ spectrophotometer connected to a rotary and a syringe pump. The monitoring system uses National Instruments LabVIEW $2010^{\circledR}$ as an operating platform. Future plans include exposing other species indigenous to Long Island Sound and also some of same species but at different life stages.

\author{
FRESH LOCAL SHRIMP IN THE NORTHEAST: CAN \\ RECIRCULATING SYSTEMS MAKE IT HAPPEN? \\ Josh Reitsma ${ }^{1}$, Ed Osmun ${ }^{2}$ \\ ${ }^{1}$ Cape Cod Cooperative Extension \& Woods Hole Sea Grant, \\ PO Box 367, Barnstable, MA, 02630, USA \\ ${ }^{2}$ E\&T Farms, 85 Lombard Ave., West Barnstable, MA, 02668, \\ USA
}

The United States imports about $90 \%$ of the shrimp consumed, creating a trade deficit of greater than $\$ 5$ billion directly related to shrimp products. The average American consumes 4.2 pounds of shrimp annually, and with such demand a consistent local source of quality shrimp should be an easily marketed high value product in the Northeast. While successful culture of Litopenaeus vannamei has been demonstrated in ponds in the southern US, recirculating aquaculture systems offer the needed environmental control to allow warm water species to be grown in the Northeast. Recent work has shown super-intensive shrimp culture systems with biofloc management to have potential, but less is known about culture potential for shrimp in more traditional recirculating systems in the Northeast. A series of trials were conducted in retrofitted tilapia and koi production recirculating systems to see if $L$. vannamei could be grown cost effectively in low salinity water. A nursery system was employed to gradually acclimate post larvae $\left(\mathrm{PL}_{12}\right)$ to low salinity water and advance growth. Survival and growth suffered in the first nursery trial due to poor water quality, though in a second trial survival improved from $7 \%$ to $86 \%$, with growth improved as well.

\author{
HIGH BRIGHTNESS LEDS DETER EIDER PREDATION \\ AT MUSSEL RAFTS \\ Donald Ronning ${ }^{1}$, Carol R. Foss ${ }^{2}$, Peter Stocks ${ }^{3}$ \\ ${ }^{1}$ Lite Enterprises, 4 Bud Way, Suite 15, Nashua, NH, 03063, \\ USA \\ ${ }^{2}$ Audubon Society of New Hampshire, 84 Silk Farm Road, \\ Concord, NH, 03301, USA \\ ${ }^{3}$ Calendar Island Mussel Company, Deakes Wharf, Portland, \\ ME, 04101, USA \\ Predation by Common Eiders (Somateria mollissima) is
} a significant limiting factor for blue mussel (Mytilus edulis) aquaculture, and is a particularly challenging problem along the Maine coast, which supports one of the world's largest wintering eider populations. We deployed high brightness blue and violet light-emitting diodes (LEDs) on two sides of a mussel raft in Casco Bay during August and September 2014. Nine, six-stone plastic fish baskets containing 500 seed mussels each were submerged from each of the two illuminated sides and from one side 
of a nearby, control raft in mid-August. When inspected on 3 October, baskets at the illuminated raft showed minimal signs of predation, while those at the control raft contained a maximum of about three dozen mussels. Further studies are needed to assess the relative effectiveness of above and below water and blue vs. violet lights, and the added value of combining lights with acoustic deterrents.

MERGING, MODELING AND MAPPING TO IMPROVE SHELLFISH AQUACULTURE SITE SELECTION Julie M. Rose ${ }^{1}$, Suzanne B. Bricker ${ }^{2}$, Tessa Getchis ${ }^{3}$, Cary Chadwick $^{4}$, Cori M. Rose ${ }^{5}$

${ }^{1}$ NOAA/NMFS, Northeast Fisheries Science Center, Milford Laboratory, 212 Rogers Avenue, Milford, CT, 06460, USA

${ }^{2}$ NOAA, National Center for Coastal Ocean Science, 1305 East West Highway, Room 8110, Silver Spring, MD, 20910, USA

${ }^{3}$ Connecticut Sea Grant, University of Connecticut, 1080 Shennecossett Road, Groton, CT, 06340, USA

${ }^{4}$ Center for Land Use Education and Research, University of Connecticut, 1066 Saybrook Road, Haddam, CT, 06438, USA

${ }^{5}$ U.S. Army Corps of Engineers, Regulatory Division, 696 Virginia Road, Concord, MA, 01742, USA

Informed site selection is essential to the successful expansion of the marine shellfish aquaculture industry. GIS-based mapping tools are becoming well-established as regulatory tools to assess potential use conflicts and environmental interactions, and industry tools to gather information on site characteristics, and the availability of land or leases. Shellfish farm models have also been used separately to optimize farm productivity, predict shellfish growth and assess farm-environment interactions. Spatial data and tools from the Connecticut Shellfisheries Mapping Atlas were integrated with the Farm Aquaculture Resource Management model at three nearshore locations in Long Island Sound. Local embayment monitoring groups assisted in sample collection. Site quality for Crassostrea virginica was based on time to harvest from one inch seed. All three sites were deemed suitable, with time to harvest varying from 278 days (high growth) to 645 days (moderate growth). Data from two long-term sampling stations, near existing shellfish leases, were used for model validation and to examine interannual variability. Both sites averaged moderate growth over the time series, 764 and 956 days to harvest, but interannual variability was high, from 308 to $>1,500$ days to harvest. Comparison of the two sites by year consistently resulted in one station yielding faster growth than the other, likely due to higher food availability and delivery at that site. These results underscore the importance of comparing sites only using data from the same time period. Combining mapping and modeling could strengthen the site selection process, particularly in locations where shellfish aquaculture is not well-established.

\section{VIBRIO PARAHAEMOLYTICUS CONTROL FOR OYSTERS IN MASSACHUSETTS \\ Chris Schillaci $^{1}$, Eric Hickey ${ }^{2}$, Michael Hickey ${ }^{1}$, Michael Moore ${ }^{3}$, Tom Shields ${ }^{1}$, Kim Foley ${ }^{3}$ \\ ${ }^{1}$ Massachusetts Division of Marine Fisheries, Shellfish} Sanitation and Management Program, 1213 Purchase St., New Bedford, MA, 02740, USA

${ }^{2}$ Massachusetts Department of Public Health, Office of Local \& Regional Health, 250 Washington St., Boston, MA, 02108, USA

${ }^{3}$ Massachusetts Department of Public Health, Bureau of Environmental Health, Food Protection Program, 305 South Street, Jamaica Plain, MA, 02130, USA

To meet federal Food and Drug Administration mandates pertaining to the consumption of raw oysters and Vibrio parahaemolyticus (V.p.), The Massachusetts Division of Marine Fisheries (DMF) and Massachusetts Department of Public Health (DPH) adopted control measures for shellfish harvesters and dealers intended to deter the post-harvest growth of $V . p$ in oysters. Historically Massachusetts had not been subject to temperatures high enough to create a significant risk of $V . p$. However, due to warming air and water temperatures, this is no longer true and since 2011 Massachusetts has experienced an increasing occurrence of $V . p$ illness related to raw oysters harvested in Massachusetts (2011-2, 2012-11, 2013-33, 2014-12). To address this risk DMF and DPH have designed a series of time-cooling, re-submergence, and record keeping requirements to minimize the risk of $V . p$ infection from oyster consumption. Initially control efforts were focused in Eastern Cape Cod Bay as exposure of oysters to the air and direct sunlight during low tide was expected to substantially increase the risk of infection. However, controls were expanded state wide as the illness pattern over the subsequent 3 years showed a significant incidence of vibrio illness associated with harvest areas in Western Cape Cod Bay and Martha's Vineyard resulting in costly area closures and recalls. A review of V.p. cases associated with Massachusetts harvest areas since 2011 shows a trend toward increased incidence in specific harvest areas and specific harvest practices, and has resulted in the development of management methodologies specific to Massachusetts industry practices.

\section{SCALLOPS AND ALGAL TOXINS - SAME THREAT DIFFERENT DAY \\ Sandra Shumway}

Department of Marine Sciences, University of Connecticut, 1080 Shennecossett Road, Groton, CT, 06340, USA

Harmful and toxic algal blooms are a global issue, threats to human health, and they continue to plague shellfisheries and aquaculture activities. Like other filter-feeding molluscs, scallops readily accumulate algal toxins and some species sequester these 
toxins in specific tissues for extended periods of time. Further, there is strong spatial variability in toxin levels among geographic regions coupled with high individual variability of toxin accumulation and depuration among individual scallops. There is a continued quest to market whole or 'roe-on' scallops from regions impacted by toxic algae poses a serious threat to both human health and the industry overall. While there are outstanding monitoring programs in place to ensure safe seafood, there are constraints on how much product can be tested. Because of these highly variable factors, the numbers of animals sampled to guarantee statistically sound testing protocols to safeguard the public can be unrealistically high or even impossible to monitor. A brief overview of relationships between scallops and algal toxins will be presented along with information on variability of toxin accumulation and retention between individual animals, distribution of toxins among scallop tissues, and a discussion of the dangers associated with marketing or consuming whole or 'roe-on' scallops from regions prone to toxic algal blooms.

THE EFFECTS OF CANDIDATE PROBIOTICS ON SEVERAL SPECIES OF CULTURED LARVAL SHELLFISH

Saebom Sohn ${ }^{1}$, David Rowley ${ }^{2}$, David Nelson ${ }^{3}$, Roxanna Smolowitz $^{4}$, Marta Gómez-Chiarri ${ }^{1}$

${ }^{1}$ Department of Fisheries, Animal and Veterinary Science, University of Rhode Island, 170 CBLS, 120 Flagg Road, Kingston, RI, 02881, USA

${ }^{2}$ Department of Biomedical and Pharmaceutical Sciences, University of Rhode Island, 7 Greenhouse Road, Kingston, RI, 02881, USA

${ }^{3}$ Department of Cell and Molecular Biology, University of Rhode Island, 381 CBLS, 120 Flagg Road, Kingston, RI, 02881, USA

${ }^{4}$ Department of Marine Biology, Roger Williams University, 1 Old Ferry Road, Bristol, RI, 02809, USA

Shellfish aquaculture is an important industry in many countries, especially in coastal and estuarine environments. Hatcheries are the main source of seed for bivalve mollusc culture. However, these facilities can experience disease outbreaks that result in high loss of production stocks. In a previous study, we demonstrated the significant protective effects of two candidate probiotic bacteria, Phaeobacter gallaeciensis S4 and Bacillus pumilus RI06-95, against fatal infections caused by the bacterial pathogen Vibrio tubiashii in larvae of Crassostrea virginica. Here, we investigated the effectiveness of these probiotic bacteria in the treatment of larval hard clams, Mercenaria mercenaria, and bay scallops, Argopecten irradians. Molluscan larvae in $5 \mathrm{~mL}$ of filtered sterile seawater were treated with either a probiont $\left(10^{4} \mathrm{CFU} / \mathrm{mL}\right)$ or control for $24 \mathrm{~h}$, washed with sterile seawater, and then exposed to $V$. tubiashii RE22 $\left(10^{5} \mathrm{CFU} / \mathrm{mL}\right)$. The cultures were incubated at $22-23{ }^{\circ} \mathrm{C}$ for $24 \mathrm{~h}$ with gentle rocking. Larval survival was determined after 24 and $72 \mathrm{~h}$ exposures to the pathogen. Both candidate probiotics provided significant protection to hard clams, but not bay scallops. Relative Percent Survival (RPS) compared to non-treated controls on hard clams was $70 \pm 9 \%$ for S4 and $92 \pm 3 \%$ for RI06-95. In addition, the protection of probiotics on hard clam lasted up to 72 hours after addition of the pathogen. Neither showed significant differences with non-treated controls for bay scallops. Thus, these probiotics appear to have species-specific protective effects for shellfish larvae.

\section{ECONOMIC ASSESSMENT OF USING A COMMERCIAL FISHERY TO CONTROL THE INVASIVE GREEN CRAB IN} PEI

Sophie St-Hilaire ${ }^{1}$, Juergen Krause ${ }^{3}$, Kehar Singh ${ }^{1}$, Luke Poirier ${ }^{2}$, Pedro Quijon ${ }^{2}$, Ian Gardner ${ }^{1}$

${ }^{1}$ Department of Health Management, Atlantic Veterinary College, University of Prince Edward Island, Charlottetown, PEI Canada

${ }^{2}$ Department of Biological Sciences, University of Prince Edward Island, Charlottetown, PEI Canada

${ }^{3}$ Department of Business, University of Prince Edward Island, Charlottetown, PEI Canada

The European green crab is an aggressive invasive aquatic species on the Atlantic coast of Canada. The precise economic impact of this species on local ecosystems is unknown but it has had substantial direct and indirect negative effects on local species and their habit. Short-term, experimental harvests of the green crab in Atlantic Canada and the U.S. have only been temporarily successful at reducing local populations. However, this suggests that a continuous fishery on the green crab may be a viable option for managing the invasive species. For a commercial fishery to persist it would need to be profitable for the fishermen. We developed an economic model to look at the break-even point for a green crab fishery under different conditions. We explored the effect of using different fishing techniques, varying the number of crabs per trap, and changing the price of crabs on the profitability of this fishery. Our model suggests if the price for green crab is sufficiently high we should be able to control this species with a commercial fishery.

\section{GENETIC AND VIABILITY EFFECTS OF pH ON EARLY STAGES OF BAY SCALLOPS FOR RESTORATION}

Sheila Stiles, Joseph Choromanski, Dorothy Jeffress

NOAA/NMFS, Northeast Fisheries Science Center, Milford Laboratory, 212 Rogers Avenue, Milford, CT, 06460, USA

Increased acidity in seawater, which lowers $\mathrm{pH}$, can affect the development of economically and ecologically valuable marine bivalves, such as oysters, clams, and scallops. Early stages of these shellfish are particularly vulnerable to low $\mathrm{pH}$. To evaluate and determine which $\mathrm{pH}$ levels have the greatest effects, experiments 
are being conducted on early stages of bay scallops (Argopecten irradians irradians) from various genetic lines for restoration. For this purpose, bay scallops were cultured in triplicate beakers, and sampled at 3 and 48 hours, after exposure to different $\mathrm{pH}$ levels. Results demonstrated no development at all at 48 hours in a reduced $\mathrm{pH}$ of 7.2 , low development with a mean of $5 \%$ to the veliger larval stage at a high $\mathrm{pH}$ of 8.5 , and a mean of $38.4 \%$ development in a control $\mathrm{pH}$ of 8.1. Three hour samples taken for cytogenetic examination to determine chromosomal and cellular abnormalities also indicated adverse effects at very early stages. For example, fewer mitoses were observed in embryos from low $\mathrm{pH}$ cultures, which suggested delayed or arrested development. There was a significant difference among the groups at 3 hours with a mean of $49.7 \%$ normal cleaving embryos at the low $\mathrm{pH}$, compared with $67 \%$ normal embryos in the high $\mathrm{pH}$ and $79 \%$ in the control cultures. Additional studies are planned for various genetic lines to determine any differences in responses possibly attributable to adaptation to different levels of $\mathrm{pH}$ or overall to a changing climate.

\section{SUBAQUEOUS SOILS AND COASTAL ACIDIFICATION: A HYDROPEDOLOGY PERSPECTIVE \\ Brett Still, Mark Stolt}

University of Rhode Island, Department of Natural Resources Science, Laboratory of Pedology and Soil Environmental Science, Kingston, RI, 02881, USA

In the coastal zone, biological and biogeochemical processes, often coupled with anthropogenic inputs, drive $\mathrm{pH}$ variability and contribute to coastal acidity. Spatial patterns of these processes across shallow coastal estuaries are unknown. In this study, we used a hydropedological approach to assess the spatial variability of coastal acidity within two coastal lagoons and embayments in Rhode Island by measuring oyster shell dissolution, and pore water $\mathrm{pH}$ within the water column and upper $5-\mathrm{cm}$ of the underlying subaqueous soils. Sampling and monitoring sites were stratified based on soil-landscape types mapped at the great group level as Haplowassents, Sulfiwassents, and Psammowassents. We found that pore water $\mathrm{pH}$ varied significantly among soils and with depth. Median pore water $\mathrm{pH}$ was significantly greater in sandy, low organic matter content Psammowassents (7.97) than the finer textured higher soil organic matter content Sulfiwassents (7.35) and the Haplowassents (6.57) that receive groundwater discharge from the surrounding subaerial soils. Juvenile calcifying organisms can experience acidic stress at $\mathrm{pH}$ values below 7.6; thus, current acidity levels within the upper few centimeters of Sulfiwassents and Haplowassents may be low enough to impact recently set juvenile calcifying organisms inhabiting these soils. Consequently, mean shell loss over a 4-week period was significantly greater in the Sulfiwassents $(1.58 \%)$ than the Psammowassents $(0.96 \%)$, with the greatest shell loss $(24.18 \%)$ in one of our Haplowassents sites with groundwater discharge. Our research suggests that measures of pore water $\mathrm{pH}$ and shell dissolution may be helpful in developing soil interpretations regarding the effects of coastal acidity on calcifying organisms.

WHY SEADUCKS FORAGE IN MUSSEL FARMS? PREFERENCES AND EFFICIENCIES WHEN FORAGING ON CULTIVATED OR INTERTIDAL MUSSELS

Élisabeth Varennes, Magella Guillemette

Département de Biologie, Chimie et Géographie, Université du Québec à Rimouski, 300, allée des Ursulines, Rimouski, Quebec, G5L 3A1, Canada

The blue mussel Mytilus edulis is the primary farmed shellfish, but it is also a main prey for various species of seaducks. Thus, seaduck predation of mussel farms represents a substantial economic loss among mussel growers worldwide. However, the attractiveness of aquacultures for these predators is not well understood, neither are their benefits when foraging in this habitat compared to intertidal wild zones, nor the extent of losses they can cause. To explore these issues, we conducted a series of experiments in controlled conditions with captive common eiders (Somateria mollissima) foraging on mussels from the two habitats (aquaculture and intertidal zone). We compared eiders' ingestion and digestion rates while foraging on both mussel types. Finally, we measured losses due to eiders' direct ingestion and fall off when foraging on a mussel collector. Eiders recognized and preferred cultivated over intertidal mussels, allowing higher ingestion rates and shorter digestion times. Moreover, underwater videos showed that one individual can clean up completely a $50 \mathrm{~cm}$-rope in approximately 3 hours (corresponding to only $4 \mathrm{~min}$ spent underwater). Because foraging in mussel farms represents such an energetic advantage, growers need to actively deal with their predation problem.

\section{SEA DUCK PREDATION IN MUSSEL FARMS: THE BEST NETS FOR EXCLUDING COMMON EIDERS SAFELY AND EFFICIENTLY}

Élisabeth Varennes ${ }^{1}$, Sveinn Are Hanssen², John Bonardelli ${ }^{3}$, Magella Guillemette ${ }^{1}$

${ }^{1}$ Département de Biologie, Chimie et Géographie, Université du Québec à Rimouski, 300, allée des Ursulines, Rimouski, Quebec G5L 3A1, Canada

${ }^{2}$ Norwegian Institute for Nature Research, Fram Centre, 9296 Tromsø, Norway

${ }^{3}$ Shellfish Solutions AS, Trondheim 7020, Norway

Shellfish aquaculture is a growing food-producing sector. The blue mussel Mytilus edulis is the primary farmed shellfish and is also a main prey for various species of sea ducks. With their large 
density of high-quality mussels, mussel farms attract these predators, and consequent depredation by ducks represents a substantial economic loss among mussel growers worldwide. Total exclusion with nets seems to be the only method that provides complete and long-term control of bird predation. The best nets for duck exclusion must be cost effective, efficient, easy to handle, and safe for bird populations. In order to identify the best net type, we tested 8 different nets under controlled conditions using captive common eiders Somateria mollissima, the largest sea duck species in the Northern Hemisphere. We identified a net with a maximum mesh size of 6 inches $(\sim 15 \mathrm{~cm})$ and large twine size to be best in excluding common eiders considering the above-mentioned criteria. Nets with thin twine and large mesh size were more likely to cause bird entanglement. In addition to using the best nets for sea duck exclusion, it is necessary to identify a target zone where such nets are the most effective. Good knowledge of the predation problem as well as collaboration among mussel growers, bird specialists, and government authorities are essential to reduce the costs and effort of installing and maintaining exclusion nets.

AN INITIAL LOOK AT BATCH CULTURE OF JUVENILE AMERICAN LOBSTERS, HOMARUS AMERICANUS, AT THE SOUND SCHOOL AQUACULTURE CENTER

Sarah Vedder, Erin DeBiaso, Britney Wrightington, John Roy

Sound School Regional Aquaculture Center, 60 S Water Street, New Haven, CT, 06519, USA

Students at the Sound School Regional Aquaculture Center in New Haven, Connecticut have been engaged in hatching American Lobsters, Homarus americanus, for over a decade. During the spring of 2014 both the initial hatch and the number of animals that reached the fourth instar surpassed all of the previous efforts. An attempt was made to batch culture a group of these newly settled benthic forms. One hundred and twenty fourth instar lobsters were selected for the study. Only lobsters that were not damaged from fighting in the planktonic stages were chosen. A 440 liter recirculating system that contained three 97 liter glass tanks $(120 \mathrm{~cm} \times 33 \mathrm{~cm} \times 33 \mathrm{~cm})$ was used for the study; salinity was maintained at $24 \mathrm{ppt} \pm 2 \mathrm{ppt}$; water temperature was $20^{\circ} \mathrm{C} \pm 2^{\circ} \mathrm{C}$ and nitrogenous product was controlled through water changes $(<0.05 \mathrm{ppm})$. Each of the three tanks was stocked with 40 lobsters. One of the tanks was maintained as "bare glass" and held only the lobsters and water. Structure was added to the second tank in the form of 40 assorted PVC pipe fittings $</=$ to $2.54 \mathrm{~cm}$ interior diameter. The third tank was stocked with matching PVC couplings and a substrate of aquarium gravel $1.5 \mathrm{~cm}$ deep. The trial ran from May $13^{\text {th }}$ until July $9^{\text {th }}$. At the close of the study 8 lobsters remained from the original 120 animals; 3 lobsters were alive in the bare glass tank; 2 lobsters were in the PVC tank and 3 lobsters were alive in the $\mathrm{PVC} /$ gravel tank.
COMPARISON OF GROWTH AND SURVIVAL OF THE LARVAL EASTERN OYSTER (CRASSOSTREA VIRGINICA) FED BY DIFFERENT METHODS

\section{David J. Veilleux, Lisa M. Milke}

NOAA/NMFS, Northeast Fisheries Science Center, Milford Laboratory, 212 Rogers Avenue, Milford, CT, 06460, USA

Different methodologies have been developed at the Milford Laboratory to feed larval bivalves, using calculated batch feeding rations, and pulse feeding using fluorometers to maintain constant food rations. This experiment was designed to directly compare growth and survival of larvae fed by these differing methods. Two day old larval oysters (Crassostrea virginica) were placed in 15 liters of static $1 \mu \mathrm{m}$ filtered seawater at a concentration of $10 \mathrm{ml}^{-1}$, and were exposed to Tisochrysis lutea (T-iso) via one of four different feeding methods: (1) demand feed using fluorometry to maintain constant $\mathrm{T}$-iso concentrations at 2,333 cells per $\mathrm{ml}$ of culture water; (2) incremental feeding, which increases the amount of algal cells using calculations based on growth; (3) modified batch feeding; and (4) an unfed control. At the end of the experiment on day 8 (10 day old larvae), there was no significant difference in number of live animals remaining per treatment. There was also no significant difference in shell height among the feed delivery methods, although all fed treatments were significantly larger than unfed $(P<0.05)$. It appears that the three feeding methods discussed do not significantly impact growth or survival of larval oysters during the first 8 days of feeding.

\section{APPLYING LAGRANGIAN DRIFTERS AND HYDRODYNAMIC MODELING TO SITE SELECTION IN SHELLFISH AQUACULTURE}

Pandora Wadsworth, Scott Rutherford, Dale Leavitt

Roger Williams University, One Old Ferry Road, Bristol, RI, 02809, USA

The success of a shellfish farm depends to a large degree on the selection of a proper site. A suitable site is dependent on water circulation in the area and knowledge of the circulation patterns can improve the efficiency of site selection. In Narragansett Bay, determining water circulation patterns can help identify sites with high water flow or help reject sites prone to biofouling. Additionally, the ability to predict the abundance of larvae at the site through water circulation patterns will benefit farms that rely on spat collectors for seed procurement. To track hydrodynamic conditions and larval dispersal, Lagrangian subsurface drifters were deployed at six locations throughout Narragansett Bay during May to October. The resulting drifter tracks showed unique hydrodynamic patterns at each deployment site and implied differences in the rate of water exchange and invertebrate larval dispersal. At the primary convergence site between the East and West passages of Narragansett Bay, the drifter tracks indicated the mixing pattern was random. At other deployment sites, the drifter tracks either showed widespread larval dispersal 
and extensive water exchange, or remained in the vicinity of the site and suggested high larval settlement and/or limited water exchange. The in situ drifter tracks were also compared to passive particle transport simulated by a Regional Ocean Modeling System (ROMS) applied to Narragansett Bay. The comparability between the modeling system and the drifter deployments varied greatly among sites. With adequate verification, hydrodynamic characterization of local waters can contribute to the site selection process for shellfish aquaculture.

DEVELOPMENT OF NOVEL ANTIFOULING COATINGS FOR THE AQUACULTURE INDUSTRY

Alex Walsh ${ }^{1}$, Sandra E. Shumway ${ }^{2}$, Stephan G. Bullard ${ }^{3}$, Steven W. Fisher $^{4}$

${ }^{1}$ Netminder, LLC, 25 Research Road, East Falmouth, MA, 02536, USA

${ }^{2}$ Department of Marine Sciences, University of Connecticut, 1080 Shennecossett Road, Groton, CT, 06340, USA

${ }^{3}$ University of Hartford, Hillyer College, 200 Bloomfield Avenue, West Hartford, CT, 06117, USA

${ }^{4}$ Netminder, LLC, 1155 Youngsford Road, Gladwyne, PA, 19035, USA

Biofouling is ubiquitous in the marine environment and inarguably one of the most serious problems facing aquaculture. Considerable research has been carried out during the past several decades to develop means of prevention and control of biofouling, yet most methods are designed to remove fouling once established. Currently no cost-effective means of eradication or control are available. Novel non-toxic antifouling coating technology developed for the aquaculture industry is presented which relies on the photoactive generation of hydrogen peroxide to reduce the settlement of biofouling organisms rather than the leaching of pesticides. Traditional antifouling paints used for boat hulls are based on copper, and often contain booster biocides. Copper is toxic to shellfish, impairs olfactory organs of anadromous fish, and persists in the environment. Photoactive release coatings provide a viable solution for minimizing biofouling on aquaculture netting, cages, and tanks. Biofouling resistance of photoactive coatings was evaluated at the University of Connecticut (Avery Point) for 12 months. Biofouling weight and percent coverage of test surfaces is reported. Antifouling efficacy of photoactive coatings on nylon and HDPE netting, PVC-coated cage used for shellfish and finfish aquaculture, and experimental panels was determined over 6 months in several geographic regions globally through a controlled series of biofouling settlement assays. Toxicity of coating materials to scallop and oyster larvae at concentrations of $0.02,0.2$ and $2.0 \mathrm{ppm}$ is reported and compared to the toxicity of copper-based antifouling paint. Results from antifouling resistance testing demonstrate the promise of photoactive coatings for biofouling control.

\author{
NOVEL ANTI-PREDATOR COATINGS FOR SHELLFISH \\ AQUACULTURE \\ Daniel Ward ${ }^{1}$, Alex Walsh ${ }^{2}$ \\ ${ }^{1}$ Ward Aquafarms, LLC, 51 North Falmouth Highway, \\ North Falmouth, MA, 02556, USA \\ ${ }^{2}$ ePaint Company, 19 Research Road, Falmouth, MA, 02536, \\ USA
}

In the northeastern United States, one of the most pressing issues for shellfish aquaculturists is the constant threat of predation. In different environments, the issue may be oyster drills (Urosalpinx cinerea), sea stars (Asterias vulgaris), moon snails (Euspira heros) in addition to many others. When culturing species which reside in cages or bags above the sea floor (i.e., eastern oyster, Crassostrea virginica), despite decades of research, there remain no environmentally sustainable methods to control invertebrate predators. The use of copper anti-fouling agents is not recommended near shellfish aquaculture operations because the metal can leach into the environment and have unintended consequences. Therefore, aquaculturists are currently forced to include losses from predators in their economic calculations, and remove predators manually which is both labor and cost intensive. Several commercially available active compounds were evaluated which could be integrated into coatings for aquaculture gear: ECONEA, capsaicin, and menthol. The efficacy of each compound was determined within different coating matrices and in mesocosm experiments. ECONEA reduced oyster drill prevalence on the coated surfaces by $48.2 \%$ compared to controls. Capsaicin and menthol reduced oyster drills on the coated surfaces by $22.2 \%$ and $33.3 \%$, respectively; ECONEA was proven to be lethal to invertebrates throughout the trials and is not a viable anti-predator compound to be used near commercial shellfish farms. Capsaicin and menthol each reduced predator movement, though the exact concentration and precise carrier formulation still requires further investigation.

\section{REMOTE SETTING TRAINING PROGRAM: SUPPORTING SEED PRODUCTION FOR MARYLAND OYSTER GROWERS \\ Don Webster ${ }^{1}$, Don Meritt ${ }^{2}$, Alan Roache ${ }^{2}$, Steven Weschler ${ }^{2}$, Stephan Abel $^{3}$, Jillian Parisi ${ }^{3}$ \\ ${ }^{1}$ University of Maryland Extension, WREC, PO Box 169, Queenstown, MD, 21658, USA \\ ${ }^{2}$ UMCES Horn Point Hatchery, PO Box 775, Cambridge, MD, 21613, USA \\ ${ }^{3}$ Oyster Recovery Partnership, 1805A Virginia Street, Annapolis, MD, 21401, USA}

Remote setting is a form of oyster seed production originating on the US West Coast and transferred to the Mid Atlantic in 1982. It is used for spat on shell seed for planting bottom leases. Early adaptation of the process was carried out with leaseholders 
through extension programs. Disease epizootics during the late 1980s led to severe decline of the resource and industry. In 2010, reopening of leasing occurred with laws mandating the use or surrender of grounds. To support the new industry, a series of programs were developed. The Remote Setting Training Program was funded by NOAA and the Maryland Department of Natural Resources and teamed the Oyster Recovery Partnership with University of Maryland (UM) units to provide setting systems in areas surrounding the bay including tanks, pumps and blowers. Growers reserved systems on a two-week basis, providing containerized cultch and labor for setting and cleaning the units at completion. Larvae was provided at no cost to those in the program with statewide and individual training provided, as well as assessment of setting success by hatchery personnel. During four years of operation, over thirty tanks were operated in ten locations. Production grew from 32 million seed in 2011 to over 300 million annually in recent years. After learning the process, four growers built their own systems.

\section{DEVELOPMENT OF MARYLAND SHELLFISH AQUACULTURE: A TEN-YEAR ASSESSMENT Don Webster}

University of Maryland Extension, WREC, PO Box 169, Queenstown, MD, 21658, USA

The decade ending in 2014 brought many changes to Maryland shellfish aquaculture. A task force concluding in 2004 recommended the creation of an Aquaculture Review Board for tracking applications, making that process faster. It created the Aquaculture Coordinating Council (ACC), a policy group providing input to government on ways to advance all aquaculture. The ACC was instrumental in making recommendations for revision of leasing laws which began a new program in 2010 designed with minimal restrictions but with a "use or lose" concept to ensure continued production. Legislative action in 2012 consolidated aquaculture permitting in a single state agency with adequate personnel for effective operations and a negotiated Regional General Permit with federal agencies reduced oversight on limited size leases. Support programs were developed to encourage industry growth including multi-year projects for extension education programs for training new growers, lowinterest loans through an agricultural lending agency for capital, emplacement of remote setting equipment in multiple locations for growers to use to produce seed for their grounds, and grants for bottom habitat development. Additionally, a program partnering university researchers with industry to develop new systems has been used successfully by several growers. Currently the industry comprises over 4,000 acres of active leases with traditional spat on shell and water column methods being used by growers. Market expansion has been strong and annual industry growth has been documented.

\section{BIOLOGICAL RESPONSES OF MULTIPLE NORTHEAST} TAXA TO OCEAN ACIDIFICATION

Meredith M. White ${ }^{1}$, Allison C. Candelmo ${ }^{2}$, R. Christopher Chambers $^{2}$, Christopher J. Gobler ${ }^{3}$, Andrew L. King ${ }^{4}$, Nichole N. Price $^{1}$, Richard A. Wahle ${ }^{5}$, Jesica D. Waller ${ }^{1,5}$

${ }^{1}$ Bigelow Laboratory for Ocean Sciences, 60 Bigelow Drive, East Boothbay, ME, 04544, USA

${ }^{2}$ NOAA/NMFS, Northeast Fisheries Science Center, James J. Howard Marine Sciences Laboratory, Highlands, NJ, 07732, USA

${ }^{3}$ Stony Brook University, School of Marine and Atmospheric Sciences, 239 Montauk HWY, Southampton, NY, 11968, USA

${ }^{4}$ Norwegian Institute for Water Research, Thormohlensgate 53D, Bergen, Norway, 5010

${ }^{5}$ University of Maine, School of Marine Sciences, Darling Marine Center, 93 Clarks Cove Road, Walpole, ME, 04573, USA

The number of studies on ocean acidification (OA) effects in marine organisms has greatly increased during the last decade. Most are laboratory experiments that consider responses of only a single species to the single stressor of elevated $p \mathrm{CO}_{2}$. These studies show OA effects but they underscore the need for experiments that realistically capture the conditions that future marine organisms are expected to experience. Features likely to be important in nature include variable $\mathrm{pH}$ conditions, multiple co-occurring stressors, and the role of species interactions in determining outcomes. The number of single-species, singlestressor experiments is sufficiently large, however, to draw tentative generalizations about biological responses to elevated $p \mathrm{CO}_{2}$ among populations and taxa including phytoplankton, macrophytes, molluscs, crustaceans, echinoderms, and fish. Patterns of biological response to OA among Northeast organisms are consistent with global trends. For both flora and fauna, calcifying taxa appear to be more vulnerable than non-calcifying ones to OA. Among molluses, a widely studied group with respect to OA, early life-stages are more sensitive than adults to OA. For multiple taxa, experimental data suggest that an organism's response to OA will depend in part on food (energy) availability, with impairment increasing as energy supply is reduced. Furthermore, some responses appear to be population-specific, with populations from more elevated or highly variable $p \mathrm{CO}_{2}$ conditions being less vulnerable to simulated future $p \mathrm{CO}_{2}$ levels than those from stable habitats. These early generalities highlight the importance of considering the features and variability of an organism's natural environment when designing laboratory OA experiments. 
NEW INSIGHTS INTO THE DEVELOPMENT AND FUNCTION OF HEMOCYTE TYPES IN OYSTERS Gary Wikfors

NOAA/NMFS, Northeast Fisheries Science Center, Milford Laboratory, 212 Rogers Avenue, Milford, CT, 06460, USA

One-hundred and thirty years after the first discovery of circulating defense cells in an invertebrate animal, origins and developmental sequences in invertebrate hemocytes retain elements of mystery. In the last decade, wide availability of benchtop flow cytometers and recognition that physiology and function of "white blood cells" (specifically neutrophils) in the human, innate immune system and hemocytes in invertebrates are highly conserved have enabled application of advanced, clinical tools to invertebrate immunology. Clinical methods have been adapted to categorize and quantify hemocytes in oysters and other bivalves in terms of morphology, defense function, and intracellular physiology. These methods have revealed bivalve hemocyte defense functions to be extremely robust in the face of various environmental and biological challenges. Accordingly, stresses that do cause immunomodulation are thought to be relatively severe. Beyond serving as a tool to evaluate resilience of bivalves to environmental challenges, flow cytometry has provided insights into fundamental developmental and functional relationships between sub-categories of hemocytes, chiefly agranular and granular cells. Combined with advanced imaging techniques and molecular methods, flow cytometry is providing growing evidence of a unified model of hemocyte development and regulation in oysters and other bivalves. Ten years of primary research in the Milford Laboratory, and some ground-breaking recent publications of others, provide evidence stimulating an evolving view of how hemocytes work in oysters and other bivalve molluscs. A more thorough understanding of relationships between different hemocyte types and their functions will improve interpretation of flow-cytometric data in terms of molluscan health and resistance to disease.

EUROPEAN GREEN CRABS IN SOUTHERN MAINE MARSHES: TRENDS IN ABUNDANCE AND MARSH IMPACTS

Kristin R. Wilson ${ }^{1}$, Jacob Aman ${ }^{1}$, Jeremy Miller ${ }^{1}$, Daniel F. Belknap $^{2}$

${ }^{1}$ Wells National Estuarine Research Reserve, 342 Laudholm Farm Road, Wells, ME, 04090, USA

${ }^{2}$ School of Earth and Climate Sciences, University of Maine, Orono, ME, 04469, USA

Recent studies indicate that intertidal crabs contribute to marsh erosion and loss through foraging and burrowing activities. The European green crab, Carcinus maenas, is a highly-successful invader established in Maine since the 1890s. In the mid-coast region, green crabs are implicated in the destruction of softshell clam flats, eelgrass beds, and salt marshes since 2012. This study quantifies green crab abundances at salt marshes in Damariscotta, Yarmouth, and Wells using two methods that sample different marsh habitats: fyke nets (marsh surface, fished for one full tidal cycle) and baited, modified eel traps (subtidal creeks, round traps, approximately $90 \mathrm{~cm}$ long, $1 \mathrm{~cm}$ mesh, 24-hour set). Concurrent sampling of these methods in late June and early August revealed much greater green crab activity in the tidal channel compared to the marsh surface and/or greater trap efficiency. Crab densities ranged from 0-0.5 crabs $/ \mathrm{m}^{2}$ with greater densities observed during the day for most sites and the lowest densities at Yarmouth, until September when abundances grew which may be correlated with cooling water temperatures. Trapping data from June, July, and August agree with the fyke net data and reveal that Yarmouth had many fewer crabs captured (0.2-3.0 crabs/hour) compared to Damariscotta (24.4-30.0 crabs/hour) or Wells (26.3-46.3 crabs/hour). The greatest sampling event to-date was Wells in early August, where 1,110 crabs were captured. CT scans of marsh cores reveal crab burrows in Yarmouth and Wells. Understanding spatial differences in population trends and direct impacts to marshes, may help inform management options in Maine.

GENETIC CHARACTERIZATION OF CLINICAL AND ENVIRONMENTAL VIBRIO PARAHAEMOLYTICUS FROM THE NORTHEASTERN US REVEALS EMERGING RESIDENT AND INVASIVE PATHOGEN LINEAGES Feng $\mathrm{Xu}^{1-3}$, Saba Ilyas ${ }^{1}$, Jeffrey A. Hall ${ }^{1,3}$, Stephen H. Jones ${ }^{3,4}$, Vaughn S. Cooper ${ }^{1,3}$, Cheryl A. Whistler ${ }^{1,3}$

${ }^{1}$ Department of Molecular, Cellular and Biomedical Sciences, University of New Hampshire, Durham, NH, 03824, USA

${ }^{2}$ Graduate Program in Genetics, University of New Hampshire, Durham, NH, 03824, USA

${ }^{3}$ Northeast Center for Vibrio Disease and Ecology, University of New Hampshire, Durham, NH, 03824, USA

${ }^{4}$ Department of Nature Resources and the Environment, University of New Hampshire, Durham, NH, 03824, USA

Even as gastric infections caused by the environmentallytransmitted pathogen, Vibrio parahaemolyticus have increased over the last two decades, until recently, infections 
linked to shellfish from the Northeastern US were rare. Cases have risen recently in New England, suggesting $V$. parahaemolyticus populations are changing. We examined clinical strains collected during a period of unprecedented disease in the region and compared them to environmental counterparts to identify resident and invasive lineages and to gain insight into the evolution of emergent pathogenic strains present in local waters. Genotyping and multi-locus sequence analysis of clinical isolates collected between 2010-2013 in Massachusetts, New Hampshire and Maine reveal the polyphyletic nature of pathogens. Although $80 \%$ of the clinical strains harbored the trh hemolysin either alone or with $t d h, 14 \%$ harbored neither hemolysin emphasizing a limitation for this trait in pathogen discrimination. Resident sequence type (ST) 631 strains caused multiple infections, and also show a dramatic, recent history of recombination with other clinical and with environmental lineages present in the region. ST34 and ST674 strains were linked to fewer infections but were also found as environmental isolates harboring hemolysin genes. Whole-genome phylogenies indicate ST36 strains that caused a rise in regional infections starting in 2012 following an atypically mild winter are derived from the Pacific Northwest population. This study lays the foundation for more accurate pathogenic strain detection as well as future work aimed at understanding dynamics within natural populations associated with emergence and invasion of pathogenic strain types in the region.

\section{TRAPPING GREEN CRABS (CARCINUS MAENAS) IN SALEM SOUND, MASSACHUSETTS}

Alan M. Young, James A. Elliott, Mae Taylor, Joseph M. Incatasciato

Biology Department, Salem State University, Salem, MA, 01970, USA

Since the arrival of the invasive European green crab (Carcinus maenas) in Massachusetts waters in the 1880's the species has had a significant negative impact on the soft-shell clam (Mya arenaria) industry. Various locations in New England have noted a recent increase in the numbers of green crabs with a concurrent decline in soft-shell clams. To get a better picture of the current green crab population in Salem Sound, Massachusetts, an ongoing trapping survey was initiated in July 2013 using baited traps deployed off docks once per month at several locations in Salem and Beverly harbors and the Danvers River and Bass River estuaries within Salem Sound. An additional study of bait preferences and a comparison of various commercially available traps have been conducted to assist the Massachusetts Division of Marine Fisheries in coordinating a trapping program involving several communities in an effort to reduce the density of crabs in local waters. To date nearly 4000 green crabs have been collected in our survey, with the highest catch per unit effort (CPUE) during the months of September, October and November. Very few crabs have exceeded $2.75^{\prime \prime}$ and none have exceeded $3{ }^{\prime \prime}$ carapace width. Over $75 \%$ of caught crabs have been females but only 13 out of over 2900 females were gravid. Herring proved to be the most effective bait of those tested. 